Portland State University

PDXScholar

\title{
Code Switching Between Tamazight and Arabic in the First Libyan Berber News Broadcast: An Application of Myers-Scotton's MLF and 4M Models
}

Ashour S. Abdulaziz

Portland State University

Follow this and additional works at: https://pdxscholar.library.pdx.edu/open_access_etds

Part of the Applied Linguistics Commons, and the Discourse and Text Linguistics Commons Let us know how access to this document benefits you.

\section{Recommended Citation}

Abdulaziz, Ashour S., "Code Switching Between Tamazight and Arabic in the First Libyan Berber News Broadcast: An Application of Myers-Scotton's MLF and 4M Models" (2014). Dissertations and Theses. Paper 1633.

https://doi.org/10.15760/etd.1632

This Thesis is brought to you for free and open access. It has been accepted for inclusion in Dissertations and Theses by an authorized administrator of PDXScholar. Please contact us if we can make this document more accessible: pdxscholar@pdx.edu. 
Code Switching Between Tamazight and Arabic in the First Libyan Berber News Broadcast:

An Application of Myers-Scotton's MLF and 4M Models

\author{
by \\ Ashour Saleh Abdulaziz
}

A thesis submitted in partial fulfillment of the requirements for the degree of

Master of Arts
in
Teaching English to Speakers of Other Languages

Thesis Committee:

Keith Walters, Chair

Kimberley Brown

Lynn Santelmann

Portland State University

2014 


\begin{abstract}
The purpose of this study is to investigate the nature of code switching between Tamazight and Arabic in light of Myers-Scotton's (MLF) (Myers- Scotton, 1993), and the 4-M model of code switching (Myers-Scotton \& Jake, 2000). Data come from the very first Libyan Tamazight news broadcast in Libya on May 2, 2011, during the uprising against the Gaddafi regime. I analyzed the broadcast in an attempt to understand the nature and implications of the switching between the two languages in the utterances of the speakers in the video. I also argued that in many ways what many might think of as code switching is actually borrowing.

During the Gaddafi era, the government banned the use of Tamazight in formal settings such as the media, work place, and schools. Since the fall of Gaddafi and his regime, the Imazighen (or Berbers) in Libya have sought to present themselves, their language, and their culture as an important part of Libyan culture. Libya's Imazighen are bilingual speakers, a fact that set up the conditions for the switching between Tamazight and Arabic analyzed in this study. Their bilingualism, along with Libyan language policies under Gaddafi, help account for the nature of code switching in the data.

This study documents contact phenomena among different languages in Libya. It also facilitates understanding of some of the sociolinguistic changes occurring there as a result of the political changes in the wake of so-called "Arab Spring."
\end{abstract}




\section{Acknowledgments}

First of all, I would like to say a big thank you to my academic advisor, thesis advisor, and mentor at Portland State, Professor KEITH WALTERS, for unlimited support from the first day I decided to attend Portland State and work with him. Thanks to his guidance and patience during moments of frustration and stress, I made it through. Thank you very much for believing in me. I would like to express my gratitude and appreciation for everything you have done for me and my family.

My deepest gratitude goes to the two people who believed in me, and gave me endless love and support—my parents. No words can ever express my love and appreciation to them.

I also want to thank Professor Kimberley Brown for her support and guidance through the years I spent at Portland State. Thanks for being there for me whenever I needed you. You have been like a mother to me.

My thanks and appreciations are also extended to Professors Susan Conrad and Lynn Santelmann for their invaluable support, advice, and understanding. I would like to extend my appreciation to my other professors, my cohort, and friends in the department as well. A special thank you to Eric Dodson, Erin Watters, Linda Boekelheide, and Shawn Walker for their support and help with editing the many drafts of this thesis throughout the long months this work has been in progress. A big thank you, too, to my generous informants, Mr. Adel Alhajaj and Mr. Nabil Abdurrahman, for their time and 
the valuable information they provided. Thanks, also, to Akli Shaka for helping with translating the video into Arabic.

Thanks to Dekn Abdalazez, my wife, for her support and patience during the critical moments of my graduate studies. Thanks to all of my friends, especially my former roommates, Hisham Bin Othman and Ibrahim Kremid, as well as my host family, Dave and Beth Owen, for their support and understanding during those most difficult times when war broke out in Libya.

Any mistakes and shortcomings of this thesis are mine, and I take full responsibility for them. 


\section{Table of Contents}

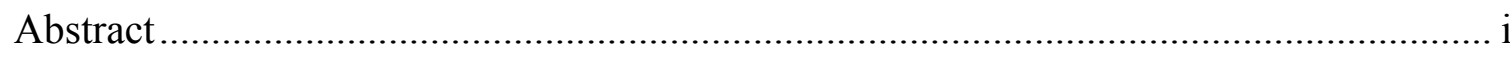

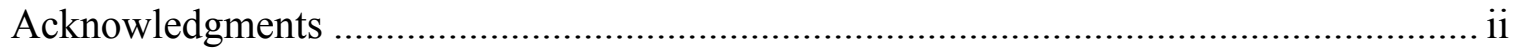

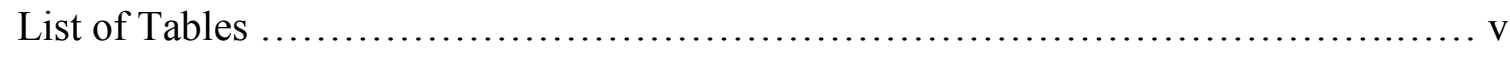

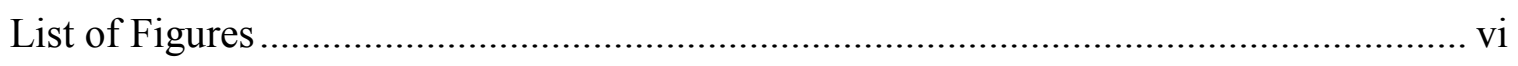

List of Abbreviations ................................................................. vii

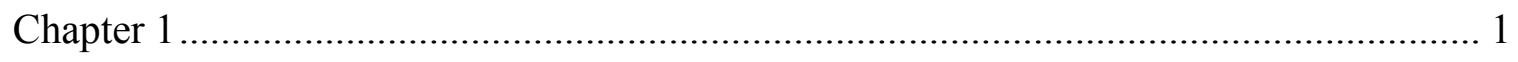

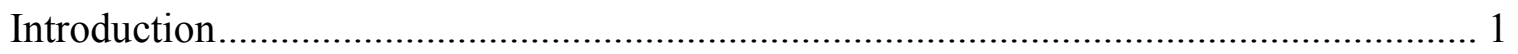

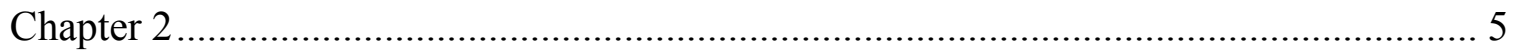

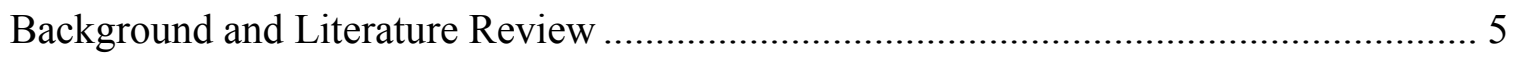

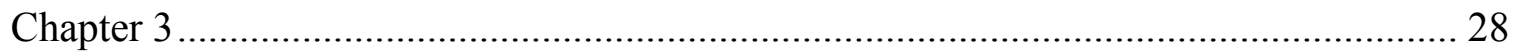

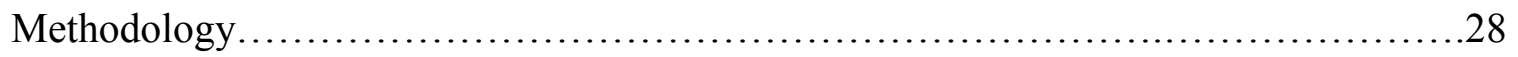

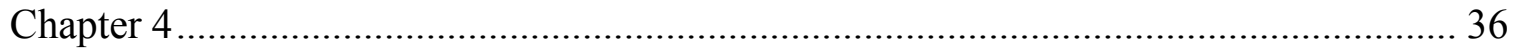

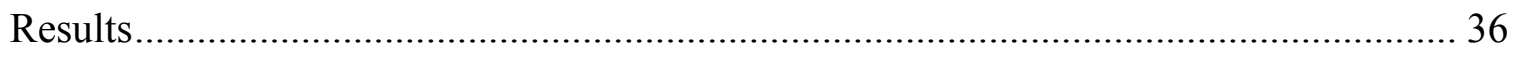

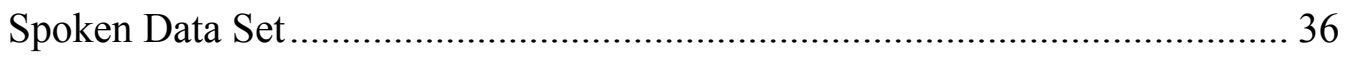

Discourse Marker /jaSni/ "I mean” ................................................................. 53

The Read-Aloud Data .................................................................................... 57

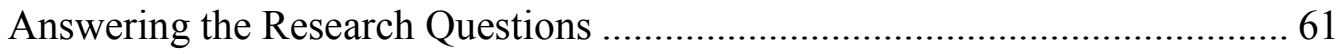

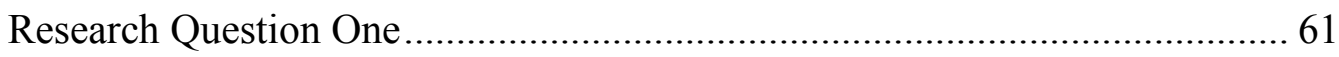

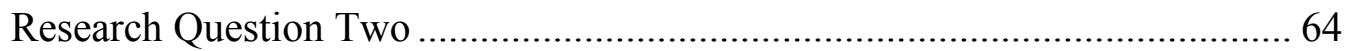

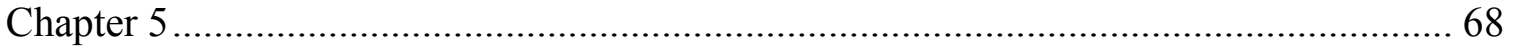

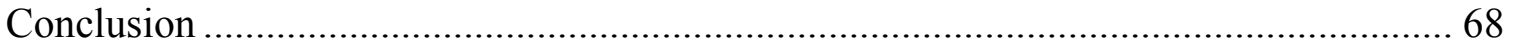

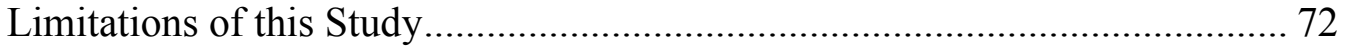

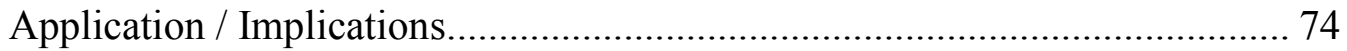

Suggestion for Future Research ................................................................ 75

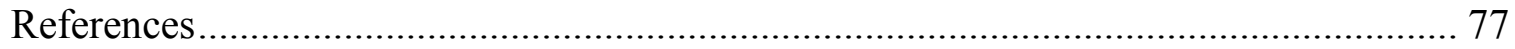

Appendix.. A Summary of the News Broadcast Video .................................................... 81 
Table 2.1: Berber and Related Terms as Used in this Thesis ........................................ 9

Table 2.2: Comparison between Tamazight and Arabic Morphology and Syntax............19

Table 2.3: System Morphemes in the 4-M Model ......................................................... 26

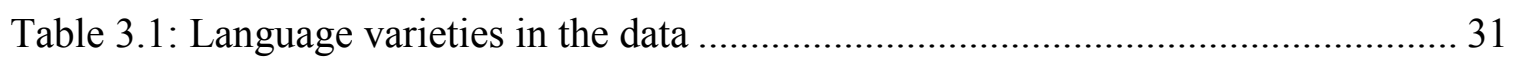

Table 3.2: Distribution of grammatical categories in the data.................................... 32

Table 4.1: Utterances in the Spoken Data by Language and by Speaker................ 37

Table 4.2: Number of pure Tamazight utterances ................................................ 44

Table 4.3: Islamic phrases originally borrowed from Arabic into Tamazight................. 48

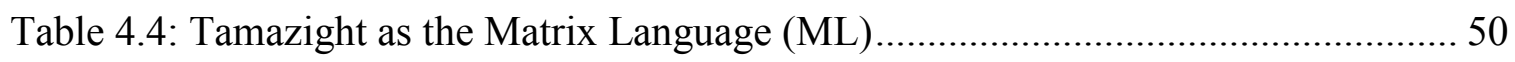

Table 4.5: Occurrences of /jaSni/ "I mean" by speaker ............................................ 54

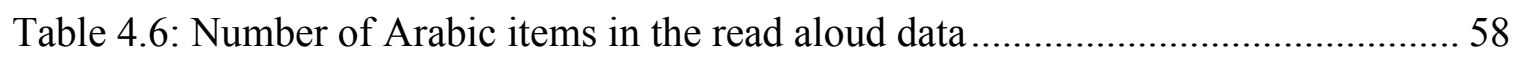

Table 4.7: Tokens and examples of Arabic numbers in the Read-Aloud Data................ 59 


\section{List of Figures}

Figure 2. 1: Map of Libya showing important cities and towns .................................... 6

Figure 2. 2: Map of the distribution of ethnolinguistic groups in Libya........................... 7

Figure 2. 3: Morpheme Classification ...................................................................... 25 


\section{List of Abbreviation}

Abbreviation

Meaning

Ar. Arabic

$\mathrm{T}$ Tamazight

MSA Modern Standard Arabic

LA Libyan Arabic

SL Standard or Libyan Arabic

B Borrowed from Arabic

F Feminine

$\mathrm{M}$ Masculine

PL Plural

SING Singular

PN Proper Noun NEG. Negation

IMP. Imperfect

CS Code Switching MLF Matrix Language Frame

ML Matrix Language

EL Embedded Language

NB Nativized Borrowing

CA Colloquial Arabic 


\section{Chapter 1}

Introduction

The last five years have been witness to great changes in North Africa and the Middle East. In Libya, these changes exploded with the 2011 revolt against and ousting of the Gaddafi regime, which led to a need to reevaluate and rewrite government policy. Language policy was one of those changes. This thesis examines code-switching between the Tamazight (Berber) language and Arabic in Libya during the first news broadcast involving Libyan Berbers, a situation where speakers of Tamazight violated long-standing policies and used their language in a public context, specifically television.

During the rule of both the Libyan monarch, King Idris I (1951-1969) and Colonel Gaddafi (1969-2011), language policy in Libya stated that Arabic was the only official language of the country with clear denial of the other languages such as the Berber languages, Tamazight and Tamahaq. In fact, these two languages were outlawed for over 60 years. With the end of the Gaddafi regime came unofficial recognition of the Berber language in the Libyan public life, through street graffiti (Abdulaziz, 2012a), and in other contexts.

Specifically, during the uprising against the Gaddafi regime in February 2011, the Tamazight language emerged in the public sphere and in the media (TV, radio, newspaper, and the internet), and the Amazigh began to broadcast news using their language, Tamazight. The major linguistic characteristic of that broadcast was code switching between Tamazight and Arabic in a broadcast that Amazigh audiences had 
likely expected to be solely in Tamazight. Television and the Internet have taken the awareness of those political, economic, and sociolinguistic changes to the world. Most notable is the current inclusion of Tamazight in addition to Arabic in news reports and media from and in some cases about Libya.

Thus, the purpose of this study is to investigate the nature of the Amazigh language at a specific period of time, May 2011, as it was used in the media and to consider what role past language policies played in shaping the language as it was used in a TV setting. To achieve this goal, I analyzed the very first Libyan Amazigh news broadcast, which occurred and was posted on YouTube on May 2, 2011, in order to investigate the nature of the Tamazight language as it was used in the media and the role that past language policies played in shaping the language as it was used in a TV setting. In looking at the nature of the relationship between the two languages, Arabic and Tamazight, in the Libyan news, this study sought to answer two specific research questions:

(1) What was the nature of the code-switching between Tamazight and Arabic in the linguistic choices the Amazigh interlocutors made on TV in light of Myers-Scotton Matrix Frame Model (MLF) (Myers-Scotton, 1993 ) and the 4-M model of code switching (Myers-Scotton \& Jake, 2000)?

(2) What influence did Arabic have over the post-February 17 Tamazight language in a TV setting as represented by the Tamazight speakers? 
By analyzing the intended segments of the video, I seek to clearly illustrate and describe some of the aspects of the complex relationship between Arabic and Tamazight, on the one hand, and the newly emerging identity of Berbers in Libya and how their identity is represented in the media both as Amazigh and Libyans in the post February 17 Libya, on the other.

My reasons for choosing to study this topic are both personal and academic. I am a Libyan who has lived most of my life in Libya and who has family, friends, and other loved ones still there. I plan to return to Libya as soon as this thesis is completed. Being outside Libya during the revolt that began on February 17, 2011, I witnessed from afar the initial revolt and the ensuing civil war between pro- and anti-Gaddafi forces, which ended with the arrest and death of Gaddafi, thanks to the aid of the international community represented by the NATO forces. Though I was in the U.S. during this period, I felt deep involvement in the events there because of TV news reports in Arabic and English that I watched via satellite television, social media websites like Facebook and Twitter, and hundreds of calls to family and friends in Libya. Those unfolding events in the country as reported and framed in Libyan and social media websites brought me in close contact and into working relationships with other Libyans-Arab, Amazigh, and Tuaregs-both in the US and in other countries.

I am also a speaker of one of the Libyan Berber varieties, Tamahaq, and I identify as Tuareg, an ethnic minority in Libya. One of the recent changes that interested me as a speaker of Berber languages is the introduction of Berber languages-Tamazight and Tamahaq-on TV and in Libyan public life more broadly. 
From an academic view point, the Berber language is an interesting case study for the sociolinguistic changes taking place now in Libya, having been outlawed for decades from use in public and official domains like education, media, and administration. One of the biggest debates in Libya now is the relationship of Tamazight to Arabic, the official language of the country. Many Amazigh activists call for inclusion of the Tamazight language in the forthcoming Libyan constitution as an additional language besides Arabic; a situation unimaginable a few short years ago.

One of the forms of contact between the Berber language and Arabic is code switching between the two languages in the media. Myers-Scotton defined code switching as "the selection by bilinguals or multilinguals of forms from an embedded language (or languages) in utterances of a matrix language during the same conversation" (1993, p.4). Using this definition of code switching, I analyzed a twenty-five minute excerpt from this broadcast as an example of code switching in the Libyan Tamazight news broadcast.

Libya's Amazigh are bilingual speakers, a fact that surely contributed to the switching between Tamazight and Arabic in this study. From the analysis, we see that the nature of this switching is not simple as some might think. Instead, the relationship between Tamazight and Arabic in most of North Africa, including Libya, is much more complicated than switching between two codes at the convenience of the speakers. 


\section{Chapter 2}

\section{Background and Literature Review}

In this chapter, I provide relevant background information on Libya and review the research on several relevant topics. After locating Libya with regard to other African nations, I present the ethnolinguistic groups in Libya: the Berbers (Amazigh and Tuaregs), the Tebou, the Ghadamses, the Arabs, and other nonnative ethnic groups. This description provides insights into the relationship between the two major language groups, Berber and Arabic, which is very important in this context, as Libya is one of the North African (Maghrib) countries where Berber speakers originated and continue to reside.

Libya is bordered by the Mediterranean Sea to the north, Egypt to the east, Sudan to the southeast, Chad and Niger to the south, and Algeria and Tunisia to the west as shown in figure 2.1 below. This location is important in understanding the Libyan people's self-image. As a North African country, Libya was an important waypoint for different conquerors and a place where many great civilizations such as the Phoenician, Roman, Greek, Ottoman, and Islamic flourished at various times. As an African country and especially because of the role Gaddafi sought to play in the Organization of African Unity, Libya is associated with contemporary political movements in the entire continent, and Libyans perceive their country as being part of Africa in ways that some other North Africans may not. 


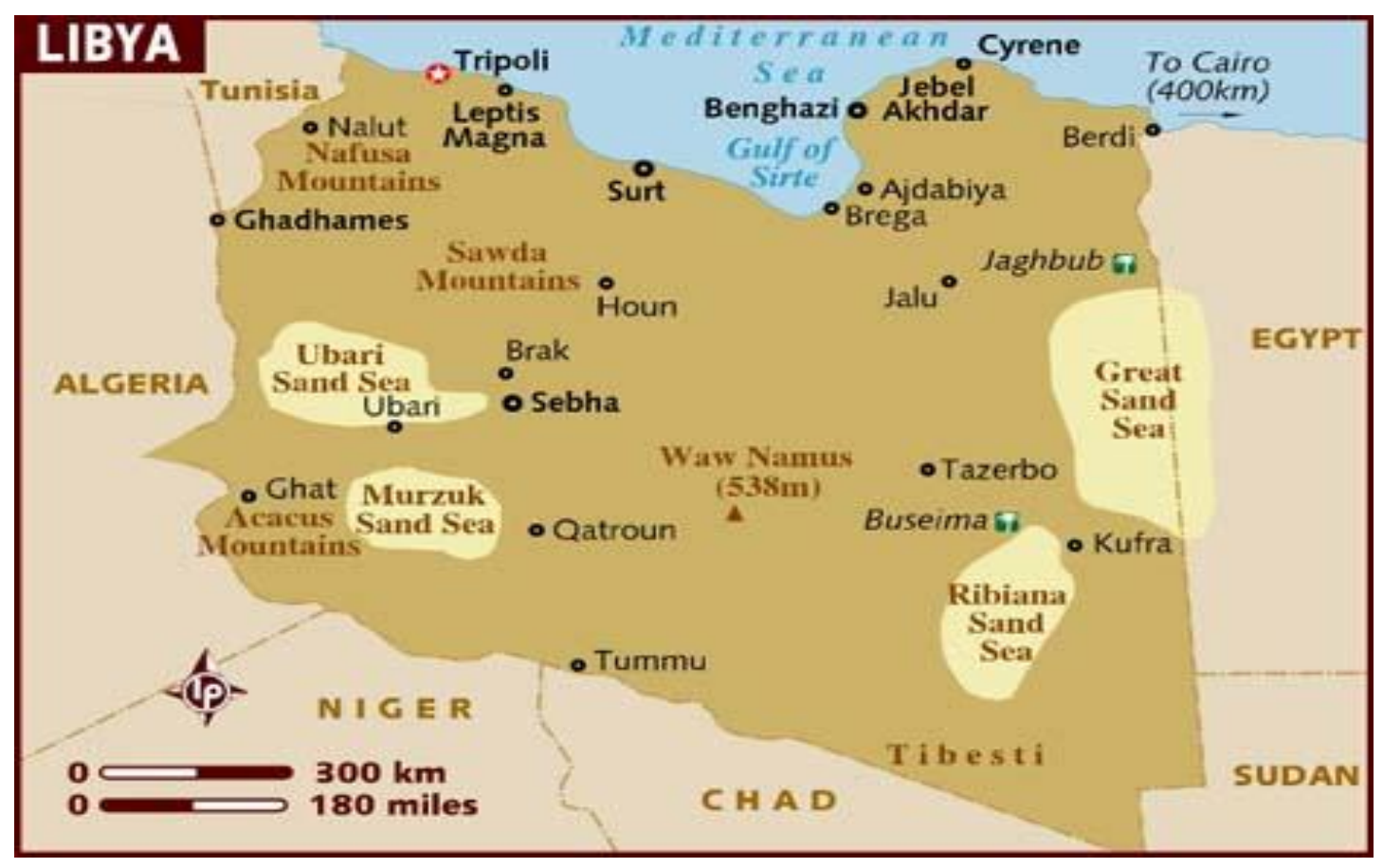

Figure 2. 1: Map of Libya showing important cities and towns (Wikipedia Commons)

\section{The Ethnolinguistic Groups in Libya}

Although Libya is a large country, 1,759,540 sq km (CIA World Fact book,

December 2013), it has a very small population of around only $6,002,347$, which includes 166,510 non-nationals, Berbers and Arabs (97\%), and other indigenous groups (3\%)

(CIA World Fact book, 2013). There are four major and distinct ethnolinguistic groups (the Arabs, Amazigh, Tuaregs, and Tebu), each with its respective ethnic language (Arabic, Tamazight, Tamahaq, and Tebu). Each language predominates in the areas where its group is heavily represented. Despite the fact that the Arabs constitute the largest ethnolinguistic group in Libya, I have concentrated mainly on the Amazigh and the Tuaregs because they are the topic of this thesis. Figure 2.2 shows the distribution of ethnolinguistic groups in Libya. 


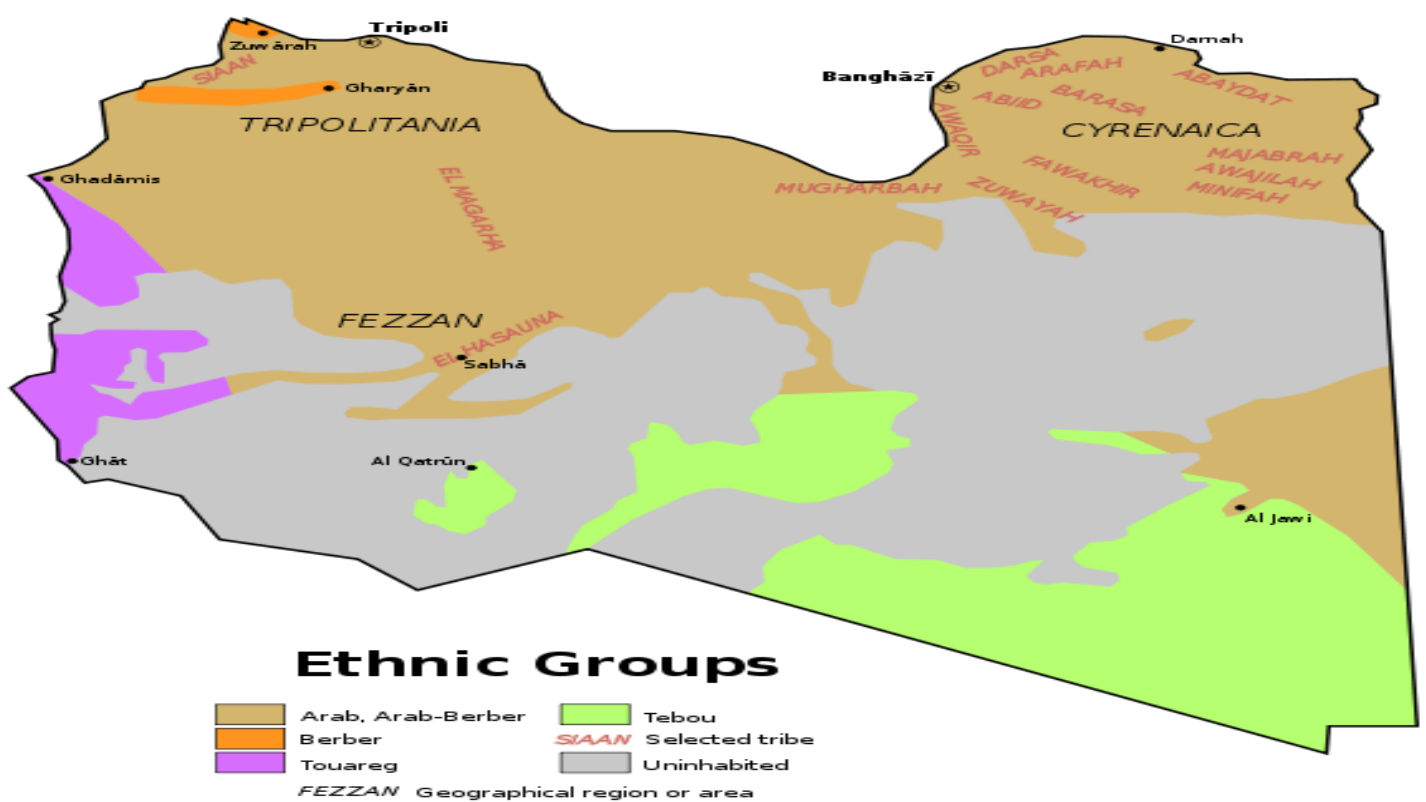

Figure 2. 2: Map of the distribution of ethnolinguistic groups in Libya (Wikipedia Commons)

First, however, let us turn to the word Berber mentioned in the previous section. In the Libyan context, this word refers to the speaker of a Berber language known as Tamazight. Two main ethnic groups are described in the literature as Berbers: the Amazigh and the Tuaregs. In Libya, the Amazigh inhabit the north and northwestern region of the country known as the Nafusa Mountain. The Amazigh are part of an ethnic group that spans parts of Morocco, Algeria, Tunisia, Libya, Egypt, Niger, Burkina Faso, Mali, and Chad. The number of Amazigh in Libya in 2011 was estimated to be around $165,000$.

The second group that falls under the umbrella of Berber is the Tuareg. In the research literature, the Tuareg are sometimes referred to as "the blue men" who then roamed the Saharan desert for centuries although, of course, there are Tuareg women as 
well as men. The Tuareg are Muslims, and Tuareg women enjoy a high status in the society as compared to the traditional Arab cultures (Harris, 1996). Traditionally, nomadic Tuareg women learned to read and write, whereas men were expected to travel in trade caravans and provide the living necessities for the family. Libyan Tuaregs are mainly found around the oases of Ghat and Ghadames (Golin, 1970), and they inhabit the northwest and southwest corners of Libya in areas bounded by the towns that grew up around these oases. Additionally, they can be found in the towns of Ubari, Wadi Utba, Idri, and in fewer numbers in the bigger cities of Sebha, Tripoli, and Benghazi to which they have migrated.

The Tamahaq language is linguistically related to Tamazight, and the two languages are mutually intelligible to varying degrees although in some political contexts, they are considered independent languages. Both Tamazight and Tamahaq employ the same traditional writing system known as Tifingh. The Amazigh and the Tuaregs refer to themselves and are referred to in the Amazigh media in Libya as the Northern Imazighen /ima:zi:yan/ "the Berbers" as in contrast to the Imazighen n Ténéré "Desert Amazigh/Imazighen," that is, the Tuaregs.

The word Berber is usually used in the literature and in everyday life in Libya and other countries of North Africa interchangeably with the word Amazigh/Imazighen, which is another umbrella term for the two ethnic groups referred to earlier as BerbersAmazigh and Tuaregs. (In fact, Amazigh is the singular form, also used as a collective noun, for 'a Berber person' while Imazighen is the plural of this word.) Table 2.1 below specifies the terms I will use in this thesis. 
Table 2. 1: Berber and Related Terms as Used in this Thesis

\begin{tabular}{|l|l|}
\hline \multicolumn{1}{|c|}{ Ethnic group } & \multicolumn{1}{c|}{ Language } \\
\hline Berber (Tuaregs \& Amazigh/Imazighen) & Berber (Tamazight \&Tamahaq) \\
\hline Amazigh/Imazighen (Northern/Northwestern Berbers) & Tamazight \\
\hline Tuareg (Southern/Southwestern Berbers) & Tamahaq \\
\hline
\end{tabular}

Thus, Table 2.1 notes that Berber is the umbrella term for both of the ethnic groups and the language varieties spoken by them. I use Amazigh to refer only to the Berbers in northern and western Libya and Tuareg to refer only to the Berber speakers in the south and southwest Libya. Likewise, Tamazight is used for the language variety spoken by the Amazigh, and Tamahaq is the variety spoken by the Tuareg. As noted, the primary concern of the thesis is code switching between Tamazight and Arabic.

In addition to Amazigh and Tuareg, there are also the people of Ghadames, who are a special case, ethnically and linguistically. Ghadames is a city of some 25,000 inhabitants on the Libyan, Algerian, and Tunisian border and a UNESCO World Heritage site (Tripoli Post, October, 2007). Many researchers (e.g. Pan, 1949; Dupree, 1958; Ayhan, 2011) categorize the inhabitants of this city as Berbers. However, based on my personal knowledge of the people of Ghadames, I would argue that they do not consider themselves to be either Arab or Berber - and definitely not Tuaregs as there are hostilities between the Tuaregs and the other people living in Ghadames, the Ghadameses. During the Libyan revolution of 2011, hostilities broke out between the two ethnic groups. Those hostilities culminated with the Tuaregs there being forced to leave Ghadames and live in a refugee camp in the desert on its outskirts (BBC, Sept. 17, 2011). Most notably, the 
Ghadameses have a strong sense of who they are not, rather than who they are. For example, international media reported the hostilities in Ghadames as being between the Tuaregs and the "mixed Arab-Berber" population (BBC, September. 17, 2011). The language spoken in Ghadames, known as Ghadamès, and it has two major dialects, Ayt Waziten and Elt Ulid. It can be seen as a mixture of Tamazight, Tamahaq, and Arabic. According to Ethnologue (2013), in 2006, there were some 10.000 speakers of

\section{Ghadameses.}

Another understudied and underrepresented ethnic group in Libya is the Tebou. Researchers like Harris (1986) labeled the Tebou as black Libyans, which might include most of inhabitants of southern Libya as well as people of Ghadames in the northwest and in the town of Tawargha on the Mediterranean coast. Thus, such a characterization is too broad. The Tebou are Saharan tribes residing the south and southeastern region of Libya. They speak Arabic as a second language, but in general, they speak Tebu, a NiloSaharan language that is spoken in southeast Libya, Chad, and Niger. There are no real estimates on the numbers of the Tebou in Libya because they are, for the most part, nomadic and travel back and forth between Libya and the neighboring countries of Chad and Niger. Furthermore, because of the nature of past Libyans regime, no information was collected on ethnic group membership or minority languages, a common practice in many countries, because such information is politically sensitive.

Ghat, my hometown, is another special case from a linguistic, ethnic and cultural point of view. Although it is usually referred to as a Tamahaq-speaking town, as noted above, it is the only place in Libya where there is an enclave of Hausa speakers. This 
situation exists because Ghat was a major trade center linking the northern citiesGhadames and Tripoli- to the Sub-Saharan countries, where Hausa is the language of trade.

The last major ethnic group that is defined as Libyan is the Arabs. Libya is known as being an Arab country, although the majority of its population is, in fact, of mixed Arab and Berber heritage. People who identify as Arabs make the largest portion of the Libyan population, especially in the north, west, south, and southeast. Ethnologue (2006) estimated that there are as 4,000,000 Arabic speakers in Libya.

Libyan society is historically tribal in nature, and most Libyans' last names derive from their tribes' names, e.g. Al-Targi. Almegrahi, Alwerfali, Al Hesnawi and Al Gaddafi, etc. In this diverse society, tensions have always existed among the different groups. Most of those tensions were ideological in the form of seeing the other groups as "them" in contrast to "us." For example, Arabs in Libya call the Amazigh jibali (someone from the mountains), or nafusi (someone from the Nafusa mountain), which most of the time is "pronounced with unmistakable scorn" (Harris 1986, p. 25). The counter attitude towards the Arabs can clearly be sensed in the Tamazight word arraaban, /arra:ban/ "the Arabs," which places Arabs as outsiders at least from the Amazigh and Tuaregs' perspectives.

Non-indigenous ethnic groups residing in Libya include Europeans, non-Libyan Arabs, other North Africans, Sub-Saharans Africans, Asians, and others who come to Libya mostly as expatriates. Ayhan (2011) argues that "the ratio of foreigners to the total 
population varies from year to year, but on the whole they constitute about $25-30 \%$ of the population" at any given time.

This section has presented background information on the ethnolinguistic diversity in Libya, including the ways labels for various groups and languages will be used this thesis. In the following section, I present relevant literature review on the topic of code switching, language policy in Libya, and a brief introduction to the two languages in my data.

\section{$\underline{\text { Review of Relevant Earlier Research }}$}

In this section, I present a review of literature which addresses two main topics: Tamazight language in the media and code-switching. First, however, a historical background on language policies in Libya will be necessary to understand the context and link it to the changes that have been taking place since the Libyan uprising in February, 2011.

\section{Language Policy in Libya}

In Libya under Gaddafi (1969-2011) and even during the era of the monarchy (Idris I, 1951-1969) before that, Arabic was the only legitimate and official language of the government. Although there are no documents from this period devoted explicitly to language policy, we can ascertain the policy by examining such documents as the National Report of Libya (2008) and the Libyan National Report of Adult Learning and Education (2009). The first report was presented in the International Conference on Education in Geneva, while the latter was originally printed in Arabic in Tripoli and presented in English in a UNESCO International Conference on Adult Education, Belém 
do Pará, Brazil (2008). Both documents laid out the general Libyan educational policies, including language policies in light of Gaddafi's Third World Theory (El-Kikhia, 1997), that is, the "Libyan alternative to both capitalism and communism" (Joffé, 2001, p. 81). That later report, too, suggests that one of the general objectives of education in Libya was to "enhance the students' love of the Arabic language and enable them to acquire the basics of the language and possess the communication skills" (p.5).

There was no mention whatsoever of other indigenous languages in those documents. These documents referred to other languages only as "foreign languages" as an indication of the teaching of languages of wider communication such as English, French, and Swahili that would support and comply with the Libyan foreign policy. Moreover, the only reference the government documents made to Libyan identity was to an "Arab identity." As a result, Arabic was the only language used in the country in formal situations, government documents, media, and the public landscape. Between 2000 and 2001, and as part of his language policy, Gaddafi ordered that all signs, which had been written in English and French, be written in Arabic alone. From my own experience as a guide and office assistant for a tourist agency, I witnessed the era when international visitors had to find a tourist agency based on the image of a camel led by a Tuareg man because all the signage was in Arabic, a language they could not read.

For Libyan Arabs, Arabic is not just a language; it is likewise a symbol of their Arab heritage and of belonging to the larger Arab nation. That is why an additional part of Gaddafi's policy was to enforce Arabism in various forms of Libyan everyday lives. As Harris (1986:26) noted, “After the revolution (September, 1969), efforts to erase 
vestiges of colonialism and renew pride in Arabism included campaigns to use Arabic on street signs, in newspapers, on shop signboards, as the sole language in educational instruction and in information section in the passports of foreigners seeking to enter Libya."

Until Gaddafi abandoned the whole idea of pan-Arabism for pan-African unity between 1997 and 1999, for decades he claimed to safeguard pan-Arab unity and nationalism. As Vandewalle (1998, p.6) argued, "Until his conversion to pan-African unit, Gaddafi claimed that he represented the future of pan-Arab and Arab nationalism in the Middle East." Part of Gaddafi's pan-Arabism policies was the forced inclusion of indigenous ethnolinguistic groups in Libya and neighboring countries under his ongoing process of Arabization. The Amazigh and the Tuaregs responded very differently to Gaddafi's policies. While the Amazigh refused to be classified as Arab and insisted on claiming their rights as Libyans but not necessarily Arabs, the Tuaregs were much more willing to comply with the government's will.

The United States' Department of State's 2012 Human Rights report on Libya reported the fact of the Arabic language being the only official language of Libya under Gaddafi and the denial of access to linguistic resources for the non-Arab citizens. It also pointed out that after the fall of Gaddafi in 2011, the Amazigh used their language on the radio as well as other means of written media in addition to public signs:

Under Qadhafi, Arabic was declared the only official language, and the regime denied the existence of non-Arab citizens. Amazigh people faced discrimination, including limitations on the use of their native language, Tamazight. At year's end, however, the Amazigh used their language publicly, publishing journals written in Tamazight and using their 
language on public signs and on the radio. They encouraged the new government to make Tamazight one of the official languages. (p.14)

Under Gaddafi, Libyan identity was synonymous with Arabic language and culture, but in the current debate on Berber language, identity, culture, and the rights of non-Arab citizens have arisen. These issues have added to the complexity of the language debate in Libya and raise new questions and concerns as in Sawani (2012):

The demands expressed by Libya's Amazigh range from enforcing identity and culture to upgrading the Amazigh language to the position of an official or at least a national language. Though questions about the script for writing the Amazigh language (whether this should be Tifn. gh, Arabic or European/Latin) remain unanswered, the fact that the Conference [September 26, 2011] was connected to foreign conferences raises ambiguities. There are also questions as to the suitability of this with respect to non-Berbers like the Tuareg who use a language different from the Berber tongue. (p.23)

On September 26, 2011, the Libyan Berbers held a conference in Tripoli for the first time in the history of contemporary Libya. According to General Administration of Al-Shouraffa (on-line 2011a, cited in Sawani, 2012), "the Conference was the platform for advocating and securing the rights of the Amazigh, the constitutionality of their language and its written script known as Tifināgh" (p.9).

The National Transitional Council, formed February 27, 2011, was officially established on March 5th, 2011, and dissolved on August 3, 2011; it was replaced by an interim government (August 3, 2011-October 14, 2012), which drafted a new constitution, referred to as the "Constitutional Declaration," to be put to a referendum. Regarding the language question and rights in that declaration, these were addressed in a number of articles in the constitution. Among the articles addressing the issue of 
language and language rights and policy are the following (al-Ṣalābi et al., 2011, cited in Sawani, 2012, p.11, emphasis added):

Article 1

Libya is an independent democratic state; its people are the source of authority; its capital is Tripoli; its religion is Islam; Islamic sharı 'ah is the primary source of legislation; the state guarantees non-Muslims the freedom to practice their religious observances; the official language is Arabic, with the guarantee of the linguistic and cultural rights of the Amazigh, Tabu, Tuareg and all the components of Libyan society.

Article 6

Libyans are equal before the law and equal in their enjoyment of civil and political rights and in equal opportunities as well as what is incumbent upon them of public duties and responsibilities. There is to be no discrimination between them on the basis of religion, madhab (sect), language, wealth, gender, lineage, political views, social status, tribal or regional or familial affiliation.

As can be seen above, the very first article in the declaration points out the language policy in Libya and explains that while Arabic is the official language of the country, the preservation of linguistic and cultural rights of the non-Arabic speaker citizens - Amazigh, Tuaregs, and Tibu—is guaranteed. This draft laid out the general terms of language policy, the religion of the country, and the source of its legislation, the /Sari:Sa/ (Islamic law), which are all historically and culturally related to the Arabic language.

Article 6, on the other hand, addresses language as one of the citizenship rights granted to all Libyans in the constitution along with the other rights all citizens of Libya should enjoy equally including not being discriminated against based on the language an individual speaks. Here, the language used in the article is general, and it applies to all 
languages and not any specific language or affiliation with a specific heritage. The language policy, as stated in Article 1, differs greatly from the language policy set forth by the Gaddafi regime, whereby it guarantees linguistic and cultural rights for non-Arabic speakers and non-Arabs. The issue of language policy in Libya is a current and continuing debate and is beyond the scope of this thesis.

\section{Languages in the Data}

In this section, I present information on the two languages involved in this study, Arabic and Tamazight. First, I start with an overview of Arabic. Then, I introduce Tamazight and its situation in Libya.

\section{The Arabic Language}

Arabic belongs to the Semitic group of languages, which also includes Hebrew; thus, it is an Afro-Asiatic language. There are many regional and national dialects of Arabic, such as Egyptian Arabic, and Libyan Arabic. Each of these regional dialects has several levels (Badawi, 1973) ranging from high (classical Arabic), to low (various dialects). Such levels are Classical Arabic, Modern Literary Arabic, Modern Spoken Arabic, and Modern Standard Arabic. Most Arabic speakers do not distinguish among those levels as categories because speakers refer to any spoken or written version of the Arabic language, rather than the dialect, as fus $\hbar a$ (Classical/Modern Standard Arabic).

The Arabic language is characterized by diglossia (Ferguson 1957, Walters, 2003), meaning that it has at least two varieties usually known as the High variety for the standard (fus`ћa) and the low variety for the dialect or the colloquial (ammiyyah or 
darijah) form of the language (Ferguson, 1959). Internal variation in the language across the Arabic-speaking world is related to geography, social class, gender and to some degree religious faith category: Muslim (Sunni vs Shi'aa Arabic), Christian, and Jewish varieties.

Despite the fact that Arabic is widely spoken as a first language in the Arab world, it does not necessarily enhance Arab national identity especially for non-Arab minorities. It serves instead as a religious language widely respected by followers of Islam around the world. Thus, it is a second or a cultural language for non-Arab Muslims, including those of Libya, though in many cases it is their dominant language.

Because of the pervasiveness of the Egyptian media (television, cinema, music), nearly all speakers of Arabic, including those with little education, have at least passive competence in Egyptian Arabic. More educated speakers will use these and other linguistics resources in case of communication breakdown in interdialectal interactions.

Also, because of more recent developments, especially the rise of satellite television and internet, contemporary speakers of Arabic have an increasing exposure to other national dialects in ways and to an extent their parents and grandparents did not. Because many satellite stations are located in the countries of the Gulf and employ announcers from there, Khaliji (Gulf) dialects are taking over and replacing the role Egyptian dialect has traditionally played in interdialectal interactions. The Syrian dialect is prevalent as well because of the increased Syrian drama, which is aired on satellite stations based in the Gulf, especially during the month of Ramadan. 
With regard to its structure, Arabic nouns, verbs, pronouns, and adjectives have singular, dual, and plural forms. Arabic also has a complex derivation system that is widely based on a root stem; for example, $k-t-b$ (write), from which other related words can be derived such as kataba- he wrote; kitab-a book; kutub-books; maktuubwritten, foreordained; maktab —office, maktaba —library; iktitaab —registration; mukaatib —reporter; and muktatib—subscriber.

\section{The Tamazight Language}

Tamazight is spoken primarily in North Africa and is for the most part unwritten (Weitzman, 2011). It also belongs to the Afro-Asiatic family of languages. In terms of its grammar, Tamazight nouns have masculine and feminine forms as in the words 'amghar' and 'tamghart' 'old man' and 'old woman'. In Tamazight, masculine nouns are unmarked, while the feminine are marked with $t-t$ at the beginning and the end of a word. Tamazight has two types of numbers, an unmarked singular and marked plural.

The Tamazight language in Libya is divided into various dialects. Those are: Awjila-Sokna languages, Northern Berber languages, and Zenati languages (Ethnologue, 2013). The Amazigh usually refer to those languages with names such as Tamazight, Thamazight, Zenati, Taznatit, or Zenatia, to name a few. Tamazight remains the most popular term referring to the Berber languages, and many Berbers desire a unification of the many closely related Berber languages into one standard language under the name Tamazight (Ethnologue, 2013).

Arabic and Berber are in close contact with each other as they are spoken in the same countries and regions. Most often, Berber speakers are bilinguals, and fluent in 
Libyan Arabic, but the reverse cannot be said to be true. Educated Berbers will also have mastered Modern Standard Arabic to some degree as a result of their education. Table 2.2 gives a basic comparison of the two languages from a structural point of view.

Table 2.2: Comparison between Tamazight and Arabic Morphology and Syntax

\begin{tabular}{|c|c|c|}
\hline Category & Similarities & Differences \\
\hline Phonetics & $\begin{array}{l}\text { Both languages have } \\
\text { emphatics sounds like } \\
/ t^{\complement}, d^{\complement}, s^{\complement}, \partial^{\complement} / \text { as well as } \\
\text { pharyngeal sounds. }\end{array}$ & $\begin{array}{l}\text { Arabic has diphthongs, /aj/ and /aw/, } \\
\text { whereas Berber does not. }\end{array}$ \\
\hline Morphology & $\begin{array}{l}\text { The two language have } \\
\text { similar root and pattern } \\
\text { morphology }\end{array}$ & $\begin{array}{l}\text { Arabic is trilateral whereas Tamazight is } \\
\text { quadriliteral, and both languages have } \\
\text { very distinct morphological systems. } \\
\text { Arabic borrowings into Tamazight are } \\
\text { often marked by the overt realization of } \\
\text { the final (generally) silent } / \mathrm{t} / \text { in feminine } \\
\text { nouns, }\end{array}$ \\
\hline Syntax & Both languages are SVO & $\begin{array}{l}\text { Arabic is both SVO and VSO (MSA) } \\
\text { while the dialect is clearly VSO. }\end{array}$ \\
\hline
\end{tabular}

Tamazight Language in the Media

In the wake of the "liberation" of many Amazigh cities in the western region of Libya and the absence of any sort of a central government, languages other than Arabic started to appear in new contexts, including the use of Tamazight in the newspapers, radio stations, street art, signs, internet, and TV (Abdulaziz, 2012a). Literature on Amazigh studies has long debated the nature of the name and whether the Amazigh and the Tuaregs are the same ethnic group and whether Tamazight and Tamahaq should be considered one language or distinctly different (El-Zwail \&Sloane, 2007; Golino, 1970; Goodman, 2005; Kohl, 2009; Kohl \& Fischer, 2010; Marçais et al. 1995; Nisan, 2002, 2011). This kind of debate was also present in the use of Amazigh language on the Libya the Free TV channel, which represents the Tamazight language as the language of both 
the Amazigh and the Tuaregs. These broadcasts, however, generally show a Tuareg person, Akli Shaka, speaking in Tamazight to the Amazigh audience, but switching to Tamahaq when specifically addressing Tuaregs (videos posted on YouTube, June-Nov. 2011). For example, "Message and appeal of the Tuaregs in Libya to abandon the dictator Gaddafi” (page young Tuareg in Libya, 2011) is one of the videos in which the speaker addresses the Tuaregs directly. Thus he speaks Tamahaq for that purpose. Moreover, the speaker's dress and background are more readily identified with the Tuareg identity he represents than with those of any other group. (This video can be seen at: http://www.youtube.com/watch?v=5USroOnHEW0).

\section{Earlier Research on Code Switching (CS)}

To conduct this analysis, I used the Matrix Language-Frame Model (MLF Model) put forward by Myers-Scotton (1993) in order to guide data coding and analysis. Although my original intention had been to employ the later and more robust 4-M model of code switching (Myers-Scotton \& Jake, 2000), a revision of the earlier model, I did not need to use it because the distinctions it makes were not relevant to the data I analyzed, likely because of the typological similarity of the two languages and their history of contact. Both models are discussed here.

\section{(A) Matrix Language Frame Model (MLF) (Myers- Scotton, 1993)}

Namba (2002) states that since the time this model was proposed by MyersScotton in 1993, it has seen a number of modifications although it is currently considered one of the most influential models to account for intra-sentential CS. The Matrix 
Language Model (MLF) model seeks to account for the formal constraints on CS within the sentence or, more properly, the complementizer phrase (CP). It seeks to explain where CS occurs and assumes that speakers have access to two languages as they code switch, but that they access those two languages in different ways. According to this model, speakers construct syntactic frames from the matrix languages (ML) into which they embed lexical items and in some cases structural configurations from the embedded language (EL). In this regard, switching is not the most appropriate label or metaphor for what is occurring; instead, drawing on models of language processing, Myers Scotton argued that both languages are in play though they are activated differentially.

Intrasentential switches are of primary interests to linguists because they show structural evidence of two grammars interacting simultaneously. As far as this study is concerned, Tamazight and Arabic are expected to vary in terms of their positions and identification as the matrix language (ML) and the embedded language (EL) throughout the video.

\section{(B) The 4-M Model (Myers-Scotton \& Jake, 2000, 2001)}

The 4-M model is a model of morpheme classification. It does not replace the MLF model. Instead, it offers a more precise description of morpheme types in light of their syntactic roles and how they are activated in the language production (MyersScotton \& Jake, 2009, pp. 340-341). This model uses the term morpheme to refer the "abstract entries in the mental lexicon that underlies surface realizations and to the surface realizations themselves" (p. 341). This model refines the content versus system morpheme distinction of the MLF model (Myers-Scotton \& Jake, 2000, p.3). 
To do so, it lays out three types of system morphemes: early system morphemes and two categories of late system morphemes-late bridge system morphemes and outsider system morphemes. Morphemes are classified based on their status with respect to conceptual activation; they are also classified according to how their forms participate in producing building larger constituents (p.3).

Morphemes are mainly classified in terms of their conceptual activation. Content morphemes (cat, tree, man) are conceptually activated. These are based on the speaker's linguistic intentions with respect to content. System morphemes, in contrast, are reflexes of the syntactic frame of the sentence. Myers-Scotton and Jake defined early system morphemes as "always realized without going outside of the maximal projection of the content morpheme that elects them" and "their form depends on the content morpheme with which they occur" (2000, p. 69). As in the case of content morphemes, early system morphemes are conceptually activated as well because they come out of the meaning of their content morpheme heads, which "indirectly elect" them. System morphemes are not conceptually activated because they come in a later stage in the language production. Early system morphemes, along with their content morpheme heads such as verb phrase (VP), noun phrase (NP), adjective phrase (AP), become salient in the building of basic constituent structures. (Myers-Scotton \& Jake, 2009, p. 342). Early system morphemes occur with content morphemes that elect them. They contain basic conceptual structure for conveying the speaker's linguistic intention. Definite articles are examples of early system morphemes that always occur with nouns in the case of English (p.343). 
In contrast to early system morphemes, there are two types of late system morphemes, which are structurally assigned. The term "late" here suggests that they are activated in a later stage in the language production. Where early system morphemes build the semantic structure, late system morphemes build the syntactic structure of the constituent (p.344). They build relationship within the clause. Late system morphemes are "the cement that holds the clause together" (Myers-Scotton, 2006a, p. 269). They neither assign nor receive thematic roles nor are they activated at the lemma level (Namba, 2002, p.4).

\section{(a) Bridge Late System Morphemes}

Bridge late system morphemes, as the name suggests, provide "bridges" between elements that make up larger constituents. For information about their form, they depend on information with their maximal projection as opposed to the outsider system morphemes, which depend on their information outside their maximal projection (MyersScotton \& Jake, 2009, p.345). They integrate content morphemes into a larger constituent and; they link two nouns within a noun phrase. English of is an example of a late system morpheme.

\section{(b) Outsider System Morphemes}

Outsider system morphemes differ from the bridge morphemes in that they depend on an outside source for information on their form. This information can come from another element in another constituent (p.346). Outsider system morphemes provide 
precise indexing of relationships that extend beyond word order and basic structure (p.346). They "knit together elements at another level" (Myers-Scotton, 2005, p. 25). These outsider morphemes are structurally assigned at the positional/surface level (Namba, 2002, p. 4); 3rd person singular- $s$ is an example for this type of morpheme.

Figure 2.3 below shows the classification of morphemes according to this model. Content morphemes and early system morphemes are $\{+$ conceptually activated $\}$. Within this classification, content morphemes are $\{$ thematic role +$\}$, whereas early system morphemes are $\{-$ thematic role $\}$. On the other side, late bridge system morphemes are \{-thematic role 'referring to its outside-'), and late outsider morphemes are \{- thematic role 'referring to outside + ' $\}$ and therefore, they are \{conceptually activated -$\}$.

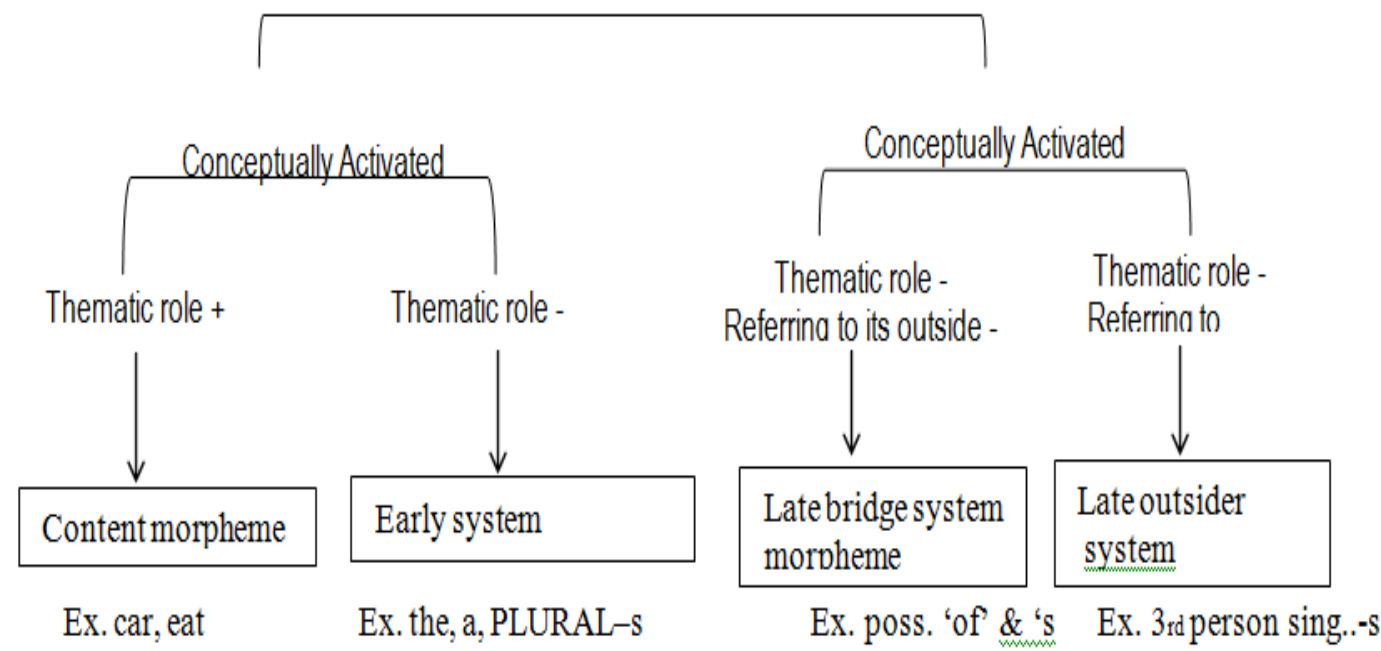

Figure 2. 3: Morpheme Classification (Namba, 2002, p.4), based on (Myers-Scotton, 2002:73)

Moreover, Table 2.2 below shows the classification, definitions and examples of different types of morphemes laid out by Myers- Scotton and Jake, as well as examples from the data. 
Table 2. 3: System Morphemes in the 4-M Model

\begin{tabular}{|c|c|c|c|}
\hline $\begin{array}{l}\text { Morpheme } \\
\text { category }\end{array}$ & Definition & $\begin{array}{l}\text { Myers-Scotton } \\
\text { examples }\end{array}$ & $\begin{array}{l}\text { Examples } \\
\text { from the data }\end{array}$ \\
\hline $\begin{array}{l}\text { (A). Early system } \\
\text { morphemes }\end{array}$ & $\begin{array}{l}\text { "are always realized without going } \\
\text { outside of the maximal projection of } \\
\text { the content morpheme that elects } \\
\text { them" and "their form depends on the } \\
\text { content morpheme with which they } \\
\text { occur." (Myer-Scotton \& Jake, 2009, } \\
\text { p. 96). }\end{array}$ & $\begin{array}{l}\text { English plural- } s \text {, } \\
\text { determiners, and some } \\
\text { prepositions }\end{array}$ & $\begin{array}{l}\text { (T) gender } \\
\text { markers; y } \\
(\mathrm{M}) \text {, and t } \\
(\mathrm{F})\end{array}$ \\
\hline $\begin{array}{l}\text { (B). Late-system } \\
\text { morpheme }\end{array}$ & $\begin{array}{l}\text { "neither assign or receive thematic } \\
\text { roles nor are they activated at the } \\
\text { lemma level." (Namba, 2002, p.4). }\end{array}$ & & \\
\hline $\begin{array}{l}\text { (1). Late bridge } \\
\text { morpheme }\end{array}$ & $\begin{array}{l}\text { "depend on information inside the } \\
\text { maximal projection in which they } \\
\text { occur" (Namba, 2002, p. 4). }\end{array}$ & $\begin{array}{l}\text { English Possessive } \\
\text { markers of }-s \text { they link } \\
\text { two nouns within a } \\
\text { noun phrase. }\end{array}$ & $\begin{array}{l}\text { (T) wan 'of' } \\
\text { (M) as } \\
\text { opposed to } \\
\text { (T) tan 'of' } \\
\text { (F) (A) inta? } \\
\text { 'of' }\end{array}$ \\
\hline $\begin{array}{l}\text { (2). Late outsider } \\
\text { morpheme }\end{array}$ & $\begin{array}{l}\text { "depend on grammatical information } \\
\text { outside of their own maximal } \\
\text { projection." (Myers-Scotton \& Jake, } \\
2000 \text {, p. 100). }\end{array}$ & $3^{\text {rd }}$ person singular $-s$ & $\begin{array}{l}\text { (T) faula.k } \underline{k} \\
\text { 'with you' } \\
\text { (M) as } \\
\text { opposed to } \\
\text { faula. } \underline{m} \text { (F) }\end{array}$ \\
\hline
\end{tabular}

In terms of differentiating cultural borrowings from core borrowings, Namba defines cultural borrowings as "words for objects and concepts new to the culture" (Myers-Scotton, 2002:41). He adds that they "often fill gaps in the recipient language (Myers-Scotton, 1993a: 206) and may appear in the monolingual speech of either bilinguals or monolinguals, or in the code switching of bilinguals (2002:41)." Cultural borrowings are expected to be open-class items.

Core borrowings, however, are "words that more or less duplicate already existing words in the L1" (2002:41) and are associated with closed-class items such as pronouns, prepositions, or conjunctions as well as morphemes serving grammatical functions. According to Myers-Scotton, "core borrowed forms typically enter the 
recipient language gradually through code-switching (2002:41), whereas cultural borrowed forms appear abruptly "for the obvious reason that they are needed to fill gaps" (1993).

In this chapter, I have introduced Libya in terms of its location with regard to other neighboring African countries as well as introducing the different ethnolinguistic group, which include the Berbers (Amazigh and Tuaregs), the Tebo the Ghadamses, the Arabs, and other ethnic groups residing in Libya for different purposes. This chapter also briefly discussed the language policy in Libya during the rule of the monarchy during the era of Idris I (1951-1969), the only Libyan monarch, and under Colonel Gaddafi (19692011). In both eras and for over 60 years, Arabic was the only official language of the country. The new draft of the Libyan constitution has also stated that Arabic is the official language of Libya with a promise to preserve the linguistic and cultural rights of the other ethnic groups.

The chapter introduced a review of the two languages involved in the data and analysis (Tamazight and Arabic). Additionally, the chapter summarized Myer-Scotton's (1993) MLF Model and the Myers-Scotton \& Jake (2000, 2001) 4-M Model, and cultural versus core borrowings.

Chapter three presents the methodology used in this study. 


\section{Chapter 3}

Methodology

In this chapter, I begin with the description of the data and the YouTube video I analyzed in this study. I then present information on data collection and procedures of analysis. Wherever necessary, I include examples in order to demonstrate how the data are organized or how the analysis was carried out.

\section{The Data}

The data for this study consisted of the video of the first Berber news broadcast in Libya. The video can be found in this link: http://www.youtube.com/watch?v=J_-

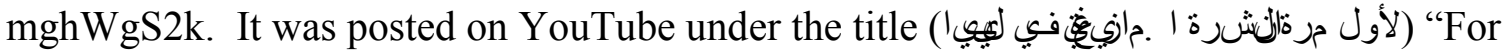
the first time Tamazight news broadcast in Libya" on May 2, 2011, the same day the actual broadcast took place on TV. The episode itself was broadcast in Doha, Qatar as part of the Libyan opposition's media propaganda against the Gaddafi regime.

The data analyzed here make up about 25 minutes of interactions between the news announcer, Azim Ali, and an analyst, Hamad Bin Khalifa, as well as interviews with other participants and read aloud news reports on the Libya Al-ahrrar (Libya the Free) TV channel. All speakers are from the mountain western region of Libya known as Nafusa Mountain - this area consists of small villages and towns, which are either Arabic- or Tamazight-speaking communities or a mixture of both.

The speakers in the video speak Tamazight and Libyan Arabic as native speakers and switched back and forth between the two languages during the broadcast. Azim is also an Arabic news announcer for the same channel. Hamad is a news analyst who is frequently hosted by the channel to comment on Libyan and specifically Libyan Amazigh 
issues. The video also included news reports by other people and an interview with a third person over the phone. (See the Appendix for a detailed description of the various segments of the video.)

The interview dealt mainly with the claims made by the state-run Libyan TV that Gaddafi's youngest son, Saif Al-Arab, had been killed in the NATO air raid on Gaddafi's house in Tripoli during the campaign against the Libyan regime in the aftermath of the February 17 uprising. Most Libyans did not believe that the news was correct, the point Bin Khalifa was trying to make in the interview.

Before 1990, Middle East and North African countries did not have access to satellite TV stations. All TV channels were state-run channels. Apart from citizens' access to news from abroad via shortwave radio, a given government could determine what information its people could have access to. With the advent of $M B C$ in September 1991, Middle Easterners and North Africans had access for the first time to television that was not created by a government agency. Since that date, hundreds of influential channels such as Aljazeera have followed. These channels broadcast either from London or from the Gulf region and are usually owned by royalty.

Aljazeera, in particular, gained unprecedented popularity during the so called "Arab Spring" revolutions that started in Tunisia and extended into Egypt, Libya, Yemen, Bahrain and Syria; in fact, media wars have been part of the conflict taking place on the ground between the government supporters and opposition. Aljazeera is seen as having played an important and critical role in bringing down such regimes as those in Tunisia, Egypt, Libya and Yemen. In the Libyan scenario, both the government and opposition 
became involved in media propaganda. Libya Alћurra $T V$ was part of such war against the Gaddafi regime. The channel started as an Arabic-speaking media apparatus of the Libyan opposition that was based in Doha, Qatar. Initially, a crew of five, all speakers of Tamazight, initiated a one-hour Tamazight news broadcast, and later they expanded the broadcast to include several talk shows as well.

\section{The Analysis Procedures}

I analyzed the 25-minute broadcast data using the following steps: First, I transcribed the video. Adel Alhajaj and Nabil Abdurrahman, both of whom native speakers of Tamazight from the city of Zuwara, assisted me with the transcription. I asked their assistance to help with the words and phrases that were harder for me to understand and some cultural references that I was not familiar with as someone who is not Amazigh or from western Libya. For example, I wondered why Azim always referred to Hamad as xali 'my maternal uncle,' which is not a typical speech act among Libyans. As Adel and Nabil explained to me, it is only in the West Mountain region and Zuwara that an individual would refer to an older or a respected man as xali. In the rest of the Amazigh communities as well as among Libyan Arabs and Tuaregs, one would refer to the same person as Sammi: 'my paternal uncle.' I also asked three other Libyan Berber speakers to help with a few questions that came up in the process of writing this thesis.

Second, I glossed the data on a morpheme-by-morpheme basis. The third step in the analysis was translating the data. Finally, I classified the data into five categories. Based on the language variety/varieties a word may belong to: (1) Modern Standard Arabic known as fus ha; (2) Libyan Arabic (LA), which refers to the Arabic variety spoken in Libya; (3) Forms that are both Standard/Libyan Arabic (SL); (4) Tamazight 
(T), the Berber language variety spoken by the Libyan Amazigh; (5) Borrowings (B) or nativized borrowings (NB); and these are words that are borrowed into Tamazight from Arabic. In these borrowings, speakers have changed the phonology or morphology of a word so that it sounds like a native Tamazight word and corresponds to phonological and morphological patterns of Tamazight. Table 3.1 below shows the language varieties in the data.

Table 3. 1: Language varieties in the data

\begin{tabular}{|c|c|c|}
\hline Language variety & Criteria & Examples \\
\hline $\begin{array}{l}\text { Modern Standard } \\
\text { Arabic (MSA) }\end{array}$ & $\begin{array}{l}\text { Based on native speaker intuitions in } \\
\text { classifying spoken Arabic words as } \\
\text { standard/dialect }\end{array}$ & $\begin{array}{l}\text { j.uku:n 'he is' (be) } \\
(3 \mathrm{msg})\end{array}$ \\
\hline Libyan Arabic (LA) & $\begin{array}{l}\text { Based on the phonology of the words } \\
\text { that would be recognized as spoken in } \\
\text { Libya or in the Maghrib region of } \\
\text { North Africa. Also based on my } \\
\text { intuitions and experience as native } \\
\text { speaker of the Arabic dialect spoken in } \\
\text { Libya. }\end{array}$ & ta:nijan 'second' \\
\hline $\begin{array}{l}\text { Standard/Libyan } \\
\text { (SL) }\end{array}$ & $\begin{array}{l}\text { Words in this category can be placed } \\
\text { under either the standard or the dialect } \\
\text { category. The phonology of such } \\
\text { words does not change when moving } \\
\text { from the standard down to the dialect }\end{array}$ & $\mathrm{s}^{\varsigma} \mathrm{u}$ 'correct' \\
\hline Tamazight (T) & $\begin{array}{l}\text { Tamazight words are those which are } \\
\text { essentially Tamazight and do not exist } \\
\text { in Arabic. }\end{array}$ & awa:1 'speech' \\
\hline $\begin{array}{l}\text { Borrowing/Nativized } \\
\text { borrowing from } \\
\text { Arabic }\end{array}$ & $\begin{array}{l}\text { These are words with Arabic } \\
\text { typological roots. Such words would } \\
\text { have a slight change in their } \\
\text { morphology either in the beginning or } \\
\text { the end of the word }\end{array}$ & $\begin{array}{l}\text { jamat 'he dies' } \\
\text { die.imp. (M) }\end{array}$ \\
\hline
\end{tabular}

To illustrate the variation of Arabic, let us look more closely at the word /j.uku:n/ 'be' (M). We see that it was pronounced as [jaku:n] as in contrast to the Libyan dialect pronunciation /i:ku:n/. Also the word /ta:nijan/ 'second' is in Libyan Arabic as opposed 
to standard pronunciation / $\theta$ a:nijan/. These examples are shown in example 3.1 below.

Generally, I based most of my judgments on my intuitions and experience as both native speaker of Arabic and Libyan Arabic.

Example 3.1, Hamad [0:5:00-0:5:12]

fa jasni a.dali:l qad j.ukuun $s^{\varsigma} u \hbar$ jamat

so Imean DEF.proof maybe (m).it.past correct 3msg.die.PERF

LA LA LA MSA MSA SL NB. T

(so, I mean, the evidence, it might be it's true he is dead)

I also classified the words into their grammatical categories. This kind of classification enabled me to see the nature of the grammatical categories and the codeswitching taking place in this news broadcast. This classification helped me show how grammatical items in different categories were distributed. Table 3.2 shows the distribution of grammatical categories in the data. I include the discourse marker 'jaSni,' 'I mean' as a separate category as it is discussed in detail.

Table 3.2: Distribution of grammatical categories in the data

\begin{tabular}{|c|c|c|c|c|c|}
\hline Category & $\begin{array}{c}\text { Standard } \\
\text { Arabic }\end{array}$ & $\begin{array}{l}\text { Libyan } \\
\text { Arabic }\end{array}$ & $\begin{array}{l}\text { Standard/ } \\
\text { Libyan }\end{array}$ & Tamazight & Borrowed \\
\hline Noun & $\begin{array}{l}\text { ar.raћma:n } \\
\text { DEF. } \\
\text { gracious (n) } \\
\text { 'the most } \\
\text { gracious' }\end{array}$ & $\begin{array}{l}\text { ћamad } \\
\text { 'proper } \\
\text { name' } \\
(\mathrm{M}) \text { ' }\end{array}$ & $\begin{array}{l}x a: l . i \\
\text { 'uncle.my' } \\
\text { 'maternal } \\
\text { uncle' }\end{array}$ & $\begin{array}{l}\text { i.?tikrka:s } \\
\text { 'a lie' }\end{array}$ & 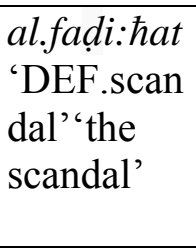 \\
\hline Verb & $\begin{array}{l}\text { mawjuuda } \\
\text { 'exists'. (f) } \\
\text { (participle) }\end{array}$ & $\begin{array}{l}\text { i.ku:nu } \\
\text { 3m.PL. } \\
\text { 'be' 'he } \\
\text { is' }\end{array}$ & $\begin{array}{l}\text { txabarad } \\
\text { 'tell' } \\
\text { (participle) }\end{array}$ & $\begin{array}{l}\text { hadrazat } \\
\text { 'talk' }\end{array}$ & $\begin{array}{l}\text { j.amat } \\
\text { 3msg.die.I } \\
\text { MP he } \\
\text { dies' }\end{array}$ \\
\hline Adjective & $\begin{array}{l}m a S r u: f \\
\text { 'known' } \\
\text { (m.participle) }\end{array}$ & $\begin{array}{l}\text { wa:ḍaћa } \\
\text { 'clear' (F) }\end{array}$ & $\begin{array}{l}\text { wa: } \hbar i d \text { 'one' } \\
\text { (M) }\end{array}$ & $\begin{array}{l}\text { jerxa } \\
\text { 'obvious' } \\
\text { (M) }\end{array}$ & $\begin{array}{l}\text { j.amat.an } \\
\text { 'they die' } \\
\text { 3PL. Die }\end{array}$ \\
\hline Adverb & $\begin{array}{l}\text { Oanijan } \\
\text { 'secondly' }\end{array}$ & $\begin{array}{l}\text { iðən } \\
\text { 'then' }\end{array}$ & $\begin{array}{l}\text { ?walan } \\
\text { 'firstly' }\end{array}$ & & \\
\hline DM-jaSni & & & jaSni & & jaSni \\
\hline
\end{tabular}


Additionally, I divided the overall exchange into turns on the basis of continued speech a speaker provided. Sometimes it was difficult to determine where a turn ended due to interruptions or overlaps from Azim, the news announcer, asking for more information or adding something to what the other speaker was saying. I determined turns to be one continuous chain of utterances on a specific topic or the answering of a certain question. Thus, for each turn, there are four lines of transcription, unless the example is in one language. The first line gives the phonetic transcription as it was heard by the researcher and the informants. The second line is a morpheme-by-morpheme gloss. The third line presents the languages, and the fourth line is a translation as in example 3.2:

Example 3.2, Hamad [0:2:42 -0:3:17]

$\begin{array}{lllll}\text { Өa:njan } & \text { ilwaqt } & \text { illi } & \text { pваnd } & \text { jafni } \\ \text { second. Adv } & \text { when } & \text { that } & \text { show.past.they } & \text { DM I mean } \\ \text { MSA } & \text { NB } & \text { T } & \text { T } & \text { LA }\end{array}$

"second, the time they showed, I mean"

Once I transcribed the text fully, I first labeled the ML and EL languages and then tested the hypotheses of the MLF and 4-M model to look for cases that conformed to them or present problems for them. This analysis permitted me to answer the first research question fully and, also, it provided information to answer the second question.

\section{Planned and Unplanned Discourse}

I divided the data analysis into two parts: the spoken and the read-aloud data sets. Here, I give a short overview of what researchers think about the characteristics of both types of discourse. Researchers have long been interested in the different features between the written and spoken language. Ochs (1979) reframed this distinction in terms of planned and unplanned discourse. 
An example of this distinction is the observation that spoken language would generally contain little subordination but a relatively great deal of coordination. Ochs added that written language, on the other hand, would not have interactive markers, planning "fillers" and other hesitation phenomena that generally occur in spoken language. Rather, it would usually have more well-chosen words and well-organized structures. She also accounted for the differences between written and spoken languages in terms of planning: unplanned for much spoken discourse and planned for much written. The definition she provided is as follows, (Ochs, 1979:55):

(1) Unplanned discourse is a kind of discourse that lacks forethought and organizational preparation.

(2) Planned discourse is another kind of discourse that has been thought out and organized prior to its expression.

Here, although my data are not written, I assumed that what is labeled as readaloud was an accurate representation of what had been written. Therefore, I make the argument that the data that are read aloud should be seen as planned data since they were written with the understanding that they would be read aloud. As demonstrated in Chapter 4, the distinction between spoken-language data and read-aloud data helps account for some of the differences in patterns of switching found in the two data sets.

\section{The Challenges of Labeling: A Switch or a Borrowing}

Determining whether a word is a switch or a borrowing is not a simple task. Labeling was the biggest challenge I faced while writing this thesis. If a word was used by the Tamazight speakers but it seemed to have Arabic roots, its nature was sometimes 
difficult to determine. In many cases, I could not find good answers to the question of the origins of a word. Thus, these words could be a result of the speakers of these two languages living together for centuries, including among them many bilinguals, or a result of other language contact phenomena. They could also be a direct or indirect result of the previous Libyan government and its Arabization and language policies more broadly. It was also difficult for my informants to determine whether a certain word was originally Arabic or Tamazight. Therefore, whenever I had doubts about a word, I stated my reasons for labeling it as a switch or a borrowing. 


\section{Chapter 4}

Results

Included in this chapter are the results of the analysis, which are centered on the two research questions:

(1) What was the nature of the code-switching between Tamazight and Arabic in the linguistic choices the Amazigh interlocutors made on TV in light of Myers-Scotton Matrix Frame Model (MLF) (Myers-Scotton, 1993) and the 4-M model of code switching (Myers-Scotton \& Jake, 2000)?

(2) What influence did Arabic have over the post-February 17 Tamazight language in a TV setting as represented by the Tamazight speakers?

\section{Overview of the Chapter}

This chapter discusses the types of code switching (CS) found in the data.

Here I discuss the analysis of two types of data: the spoken language and the read-aloud data, partitioned as explained in Chapter 3. In the first part of this chapter, I discuss the spoken data according to type, language, and speaker. The spoken data are divided into cases of pure Arabic data, pure Tamazight data, and the data in which CS occurs between the two languages. An analysis of the read-aloud data is then presented. The chapter concludes with a summary of the discussion and findings.

\section{Spoken Data Set}

As noted in Chapter 3, an utterance is defined as a complete unit of speech such as a phrase or a sentence that is spoken by a single speaker. Table 4.1 shows the tokens and the kind of utterances used by each speaker in the spoken portion of the video. 
Table 4. 1: Utterances in the Spoken Data by Language and by Speaker

\begin{tabular}{|l|r|r|r|r|r|r|r|}
\hline \multicolumn{1}{|c|}{ Spoken Utterances } & Azim & \multicolumn{1}{c|}{$\begin{array}{c}\text { Hama } \\
\mathrm{d}\end{array}$} & Mazigh & \multicolumn{1}{c}{$\begin{array}{c}\text { Gir } \\
1\end{array}$} & $\begin{array}{l}\text { Unidentified } \\
\text { voice 1 }\end{array}$ & $\begin{array}{c}\text { Unidentified } \\
\text { voice 2 }\end{array}$ & Total \\
\hline $\begin{array}{l}\text { Utterances in Arabic } \\
\text { (A) }\end{array}$ & 2 & 13 & 0 & 0 & 2 & 0 & 17 \\
\hline $\begin{array}{l}\text { Utterances in } \\
\text { Tamazight (T) }\end{array}$ & 11 & 16 & 3 & 7 & 0 & 1 & 38 \\
\hline $\begin{array}{l}\text { CS Utterances with A. } \\
\text { as the ML }\end{array}$ & 1 & 24 & 1 & 1 & 0 & 0 & 27 \\
\hline $\begin{array}{l}\text { CS Utterances with T. } \\
\text { as the ML }\end{array}$ & 44 & 117 & 14 & 0 & 0 & 0 & 175 \\
\hline Total Utterances & 58 & 170 & 18 & 8 & 2 & 1 & 257 \\
\hline
\end{tabular}

This table provides information on the spoken-language data, which excludes any texts that were read aloud. It displays the number of purely Arabic utterances, purely Tamazight utterances, utterances in which Arabic is the matrix language, and utterances in which Tamazight is the matrix language, as well as the overall number of utterances. The data are also divided by speaker as noted in chapter 3. Azim is the news announcer; Hamad is an analyst; Mazigh is a newspaper editor, who participated by telephone. The young girl is a Libyan Amazigh whose family has fled to Tunisia, and the unidentified voices belong to Libyan Amazigh fighters. I first discuss the data in terms of language, providing two examples of each category of utterance. I then comment on the examples and point out any linguistic characteristics that need to be highlighted.

The data in the Table 4.1 consist of 257 utterances in total. These utterances were divided as follows: 17 utterances as purely Arabic, 38 as purely Tamazight, 27 utterances with Arabic as the matrix language, and 175 with Tamazight as the matrix language. Thus, the majority of the utterances involve Tamazight, whether as the sole language $(14.8 \%)$, the matrix language for code switching $(68.1 \%)$, or the embedded language in 
an otherwise Arabic utterance (10.1\%). Only (6.7\%) of the utterances contained no Tamazight at all.

The purely Arabic utterances were further divided into three subcategories: those involving the fus $\mathrm{h}$ ha (MSA), those involving Libyan Arabic (LA), and those involving diglossic switching between the fus ${ }^{\mathrm{h}}$ ha and Libyan Arabic. Although these Arabic utterances included phonological and morphological items that differentiate them from one another, they are classified here as Arabic because they do not consist of any Tamazight items or items switched from any other language. The examples in the section illustrate utterances classified as MSA, LA, or diglossic switching in which both varieties co-occur in a single utterance.

Because the focus of this study is not variation in the Arabic found in the interview, I have neither calculated the number of utterances of any one variety, nor did I seek to apply Myers-Scotton's models to the cases of diglossic switching. However, in presenting the purely Arabic data, I discuss them based on these three categories: MSA, Libyan Arabic, and diglossic switching. Impressionistically, however, I would note that Myers-Scotton's models can account for all of the Arabic data.

\section{A. Pure Arabic Utterances}

\section{Modern Standard Arabic (MSA)}

Example 4. 1: Hamad [00:02:21-00:02:34]

\begin{tabular}{|c|c|c|c|c|}
\hline wa & $\begin{array}{l}\text { b.ism } \\
\text { in..name }\end{array}$ & $\frac{\mathrm{i} 1^{\mathrm{f}} \cdot 1^{\mathrm{f}} \mathrm{a}: \mathrm{hi}}{\text { the. God }}$ & $\begin{array}{l}\text { ar.rahma:n } \\
\text { the Merciful }\end{array}$ & $\begin{array}{l}\text { ar.rahi:m } \\
\text { the Compassionate }\end{array}$ \\
\hline SA & MSA & MSA & MSA & MSA \\
\hline
\end{tabular}

In the name of God, the [most] Merciful, the [most] Compassionate 
In Example 4.1, the speaker, Hamad used very formal language to start the interview. It is a common practice for Arabic speakers and many other Muslims to open a TV interview or similar speech event formally by including the opening line of the Qur'an known in Arabic as Basmala, meaning "In the name of God, the Merciful, the Compassionate," in Classical Arabic/Modern Standard Arabic and then switching to the local language (if not Arabic) or diglossically switching between the use of MSA and CA. Utterances like these are usually colored by the speaker's local dialect, even though speakers of Arabic would refer to them as fus ${ }^{\varsigma} \hbar a$ or MSA. The emphatic Arabic $\left[\underline{1}^{\complement}\right]$ has been argued to occur only in the word Allah 'God' as used in certain contexts such as the

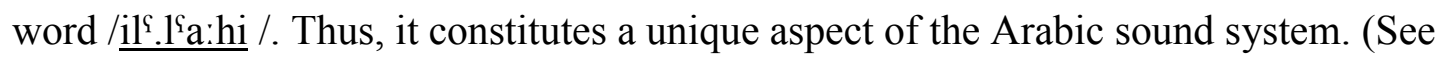
Ferguson (1956) for more information). Hamad in this example spoke in MSA with an identifiable Libyan accent. The phonology of his utterances was a mixture of MSA and LA, which makes the utterance the Libyan version of MSA.

Example 4. 2. Hamad [00:05:00-00:05:12]

$\begin{array}{lll}\text { kul } & \text { al?ћtima:la:t } & \text { mawju:da } \\ \text { all } & \text { possibility.PL. F } & \text { present.IMP.SING.F } \\ \text { MSA/LA } & \text { MSA } & \text { MSA/LA }\end{array}$

"All possibilities exist"

The same characteristics of example 4.1 are true for example 4.2. Many speakers of Arabic would argue that this example is MSA. Upon closer evaluation, however, one can note that the endings of the three words in this phrase are not marked for case as they would normally be in the most formal instances of MSA. All other MSA utterances in this data exhibit the same characteristics shown in these two examples: generally, case marking is used inconsistently, if at all, a common feature of spoken MSA. In MSA, but 
not the dialects, plural inanimate nouns, regardless of their grammatical gender in the singular, take feminine singular agreement; hence, the predicate adjective is feminine singular here. (The dialect would use a plural form in this case.) Thus, this fact is additional evidence that this utterance should be seen as MSA. Recall likewise that in Arabic, as in Semitic languages generally, the verb to be is not overtly marked in imperfective affirmative contexts.

\section{Libyan Arabic (LA)}

The second subcategory in the purely Arabic data comprises the LA utterances. In these utterances, speakers use lexical items intrinsic to Libya and/or the phonology and syntax that are exclusively associated with LA. Example 4.3 below is representative of the use of the Libyan Arabic syntax and phonology in the data. For example, within the sentence structure, the last part of the sentence /ala:h jerhamah/ would be expressed in MSA as /jarhamahu Pał'ła:h/; in other words, word order would be reversed, and the pattern of vowels would be different in the verb (including the way that the direct object 'him' is marked ([h] vs. [hu])). The expression "May Allah have mercy on his [her] soul" is traditionally used when the name of someone who has died is mentioned.

Example 4. 3. Hamad [00:19:00-00:20:23]

\begin{tabular}{|c|c|c|c|c|}
\hline $\begin{array}{l}\text { ə̧eix } \\
\text { sheikh }\end{array}$ & $\begin{array}{l}\text { Sali } \\
\text { PN }\end{array}$ & $\begin{array}{l}\text { maSama:r } \\
\text { PN }\end{array}$ & $\begin{array}{l}\text { Pal'1ৎa:h } \\
\text { Allah }\end{array}$ & $\begin{array}{l}\text { je.rhama.h } \\
\text { have.mercy. on him. IMP }\end{array}$ \\
\hline LA & $\mathrm{LA} / \mathrm{T}$ & $\mathrm{LA} / \mathrm{T}$ & LA & LA \\
\hline \multicolumn{5}{|c|}{ "Sheikh Ali Ma'mar, may Allah have mercy on his soul" } \\
\hline \multicolumn{5}{|c|}{ Example 4. 4. Hamad [00:10:15-00:10:26] } \\
\hline il.gada: & & $\mathrm{mu} \int$ & \multicolumn{2}{|l|}{ sahil } \\
\hline PN (gac & afi) & NEG. LA & \multicolumn{2}{|c|}{ easy.SING.M } \\
\hline LA & & LA & \multicolumn{2}{|l|}{ LA } \\
\hline
\end{tabular}


In example 4.4, the speaker used LA morphology when rendering the proper noun /Gaddafi/ and the LA negator/mu// "not." He also included the LA adjective/sahil/ version of the corresponding MSA adjective /sahl/. 


\section{Diglossic Switching}

The third category of the purely Arabic data involves the cases of diglossic switching within the Arabic data. In these exchanges, speakers use both MSA and LA within an utterance. In example 4.5 below, the Libyan Arabic items are in bold. The remaining items are in MSA, but spoken with the phonology of Libyan Arabic.

Example 4. 5. Hamad [00:24:29-00:25:21]

?jdfan ha:di ha:la min ha:l.a:ti al.ћarb jaSni also this.SING.F case.SING.F of case. PLF DEF.war.SING MEAN "Also, this is a case of war, I mean."

Here, the words marked as MSA can also be argued to be part of LA, but the speaker rendered these words with a near MSA pronunciation, which had the effect of elevating the language he produced, making it sound more formal in this particular setting; specifically, he used LA forms but pronounced them in a way that made them closer to their MSA equivalents than to their usual dialectal rendering. The only words in plain Libyan Arabic in this sentence are /ha:di/ and/jaSni/, which are the Libyan version of MSA /ha:ðihi/ and /?aYni/. What makes the rest of the sentence MSA is not the lexical items, but the phonetic realization of these forms the speaker uses.

Example 4. 6. Unidentified male voice [00:23:22-00:23:43]

xu:d.u: $\quad \mathrm{s}^{\mathrm{f}} \mathrm{u}: \mathrm{ra} \quad$ zamąija: $\quad$ kwjisa take.IM.PL picture.F group.F.ADJ good. SING. F LA LA LA LA "take a good group picture"

In example 4.6, the sentence consists of a verb /xu:du:/, which is LA; (its MSA equivalent is /xuðu:/ or /iltaqit ${ }^{\complement} \mathrm{u}: /$, meaning "take,"), and it is an imperative form that is 
uttered by an unidentified male voice in an authoritative tone: A noun $/ \mathrm{s}^{\mathrm{s}} \mathrm{u}: \mathrm{ra} /$, which can be either MSA and LA, functions as direct object. An adjective/3amaSija:/ modifies the noun $/ \mathrm{s}^{\mathrm{s}} \mathrm{u}: \mathrm{ra} /$, and another adjective $/ \mathrm{kwjisa}, /$, which is also in LA and modifies the same noun, $/ \mathrm{s}^{\mathrm{s}} \mathrm{u}: \mathrm{ra} /$. This latter term means "good," and it is also refers to the group picture that is being taken; (its MSA equivalent would be/zajida/). Thus, in this example, the speaker uses two lexical items that are completely LA while the other two can be argued to be either or both LA and MSA.

Such diglossic switching between MSA and a spoken national Arabic dialect is a common practice for Arabic speakers on TV and radio and in daily life. Speakers would normally start a sentence or a speech or an utterance with one form and continue switching back and forth between MSA and the particular local dialect they speak, LA in this case. A discussion of the constraints on switching between MSA and the dialect, while interesting, is beyond the scope of this thesis. See Boussofara-Omar (1999, 2003a, 2003b, 2005) for additional information and discussion.

\section{B. Pure Tamazight Utterances}

The second category in the analysis of the spoken data is pure Tamazight data set. No CS was involved in these interactions. All speakers in this broadcast were native speakers of both Tamazight and Arabic. Since this news broadcast was directed to the Amazigh audience in Libya and billed as the first news broadcast in the Libyan Tamazight, it was, therefore, intended to be in a language that would be understood by the Libyan Amazigh population. The lexical items, references, and borrowings as well as 
switches in this broadcast were intended to communicate with Libyan Berber-speaking populations, including the Tuaregs.

As in the case of pure Arabic items, the Tamazight items in the data are divided into different categories. These include pure Tamazight utterances, utterances with cultural borrowings, and those with core borrowings. Single-word utterances are not included in this analysis. Only phrases and sentences were considered in the examples given for the sake of the analysis. Here, I discuss and give examples for each of the categories below in line two "Utterances in Tamazight."

Table 4. 2: Number of pure Tamazight utterances

\begin{tabular}{|l|l|l|l|l|l|l|l|}
\hline $\begin{array}{l}\text { Spoken } \\
\text { Utterances }\end{array}$ & Azim & Hamad & Mazigh & Girl & $\begin{array}{l}\text { Unidentified } \\
\text { voice 1 }\end{array}$ & $\begin{array}{l}\text { Unidentified } \\
\text { voice 2 }\end{array}$ & Total \\
\hline $\begin{array}{l}\text { Utterances in } \\
\text { Arabic }\end{array}$ & 2 & 13 & 0 & 0 & 2 & 0 & 17 \\
\hline $\begin{array}{l}\text { Utterances in } \\
\text { Tamazight }\end{array}$ & 11 & 16 & 3 & 7 & 0 & 1 & 38 \\
\hline $\begin{array}{l}\text { Utterances in } \\
\text { which A. is } \\
\text { the ML }\end{array}$ & 1 & 24 & 1 & 1 & 0 & 0 & 27 \\
\hline $\begin{array}{l}\text { Utterances in } \\
\text { which T. is } \\
\text { the ML }\end{array}$ & 44 & 117 & 14 & 0 & 0 & 0 & 175 \\
\hline $\begin{array}{l}\text { Total } \\
\text { Utterances }\end{array}$ & 58 & 170 & 18 & 8 & 2 & 1 & 257 \\
\hline
\end{tabular}

In Table 4.2, we can see that there is a total of 38 utterances in pure Tamazight in the data. Different speakers produced different numbers of tokens of these utterances. Again, Hamad and Azim produced the majority of the utterances with Hamad accounting for 16 out of the 38 utterances and Azim 11. Moreover, the girl in the data produced 7 utterances in Tamazight; in fact, the majority of her utterances were in Tamazight, a fact 
that might have reflected her age, the context (a refugee camp in Tunisia), and her lack of experience speaking in formal contexts. In contrast, a more educated speaker might rely on the resources of Arabic more often. Mazigh produced 3 utterances in Tamazight, while the unidentified speakers produce only one purely Tamazight utterance.

\section{Purely Tamazight Utterances}

The pure Tamazight utterances did not involve a language other than Tamazight. The lexical items in these utterances included both pure and items that have been borrowed from Arabic into Tamazight. In this analysis, these borrowings are considered Tamazight; that is, these words have become fully incorporated into Tamazight and would be the word any Libyan speaker of the Tamazight language would use even though they could be analyzed as having, at one time, originated in another language, generally Arabic.

When proper nouns were examined, they were found to be identical in both Arabic and Tamazight, while it was not the same case with verbs. In example 4.7 below, the verb form "ma:fibћa:nif" "did not see" was originally Arabic in one sense. The verbal root has been borrowed into the Tamazight language from the Libyan Arabic. Additionally, the Arabic NEG markers /ma:/ and / $/$ / have also been borrowed and used with this Tamazight nativized borrowed verb. (Thus, even though a speaker of LA who does not speak Tamazight might hear this as an Arabic form, I argue it is a Tamazight form, the verb stem and the negator having both been borrowed into Tamazight.) Thus, in this example, the subject, /ilu:da:n/ 'people' and the verb /ma:fibћa:nif/ ' did not see' are 
the Tamazight items in the phrase whereas the object, /seif a:19ara:b/, Gaddafi's son's, is a proper noun that is identical in both languages.

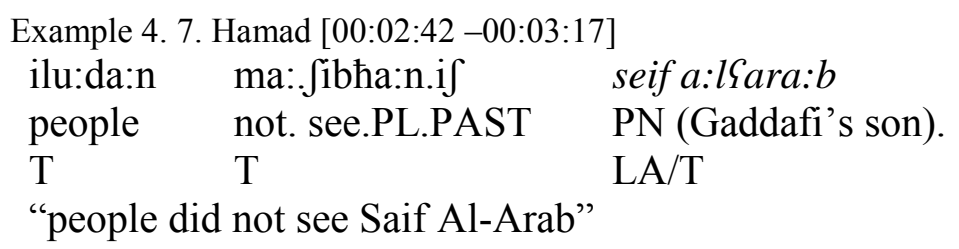

Example 4.8 below is an example of CS. Two grammatical items; /kul fa:j/, and /as'abar/ are Arabic items whereas /ва:sa/ is the Tamazight item, which carries the system morphemes.

Example 4. 8. Hamad [00:20:34-00:20:57]

$\begin{array}{lll}\text { kul fa:j } & \text { ва:sa } & \text { as`abar } \\ \text { everything } & \text { require. SING. IMP } & \text { patience } \\ \text { Ar } & \text { T } & \text { Ar }\end{array}$

"Everything requires patience"

In example 4.8, Hamad switched in the middle of the sentence when he inserted /ва:sa/, which is a Tamazight verb between two Arabic grammatical items. The Arabic items are the subject and the object of the sentence, whereas the Tamazight item is the verb of the sentence.

\section{$\underline{\text { 2. Tamazight utterances with cultural borrowing related to religion }}$}

Tamazight and Arabic have been in contact for hundreds of years, so it is natural that both languages have borrowed grammatical and lexical items from one another even though Arabic is the dominant language in the society at large. Although Arabic has historically been the only official language in Libya, intermarriages and long-term relationships between Berber and Arabic speakers facilitated the borrowing from one language to the other. Indeed, in all North African varieties of Arabic, we find a number 
of words, especially those relating to flora and fauna, many of which were borrowed from local varieties of Berber. Other categories of words or expressions have been borrowed as well.

A major reason for cultural borrowings from Arabic to the Tamazight is the fact that the Amazigh are Muslims, and the source of many terms associated with the faith is Arabic. Participants in this data used culturally oriented and religious references, not only as Libyans, but also as Muslims. From the examples below we see that Islamic phrases in this data were always in Arabic, both MSA and LA. The borrowed items are in bold.

Example 4. 9. Hamad [00:02:42-00:03:17]

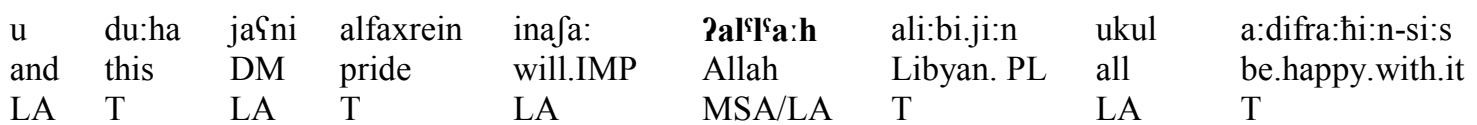
"and this, I mean, a pride for all Libyans and, if God wills, they will be happy with it"

In example 4.9 above, although there are several items in Libyan Arabic, the phrase in bold, /infa:Pat' 'la:h/ "God willing" is in MSA. Sometimes it was rendered with MSA phonology and other times with LA phonology (infa:alla). In other words, both of these versions of the phrase have been borrowed from MSA and LA into the Tamazight language. Based on the context, a speaker chooses which form to use in a particular situation, as is customary when referring to future events, especially hopes that something will change for the better. This particular phrase occurred 19 times in the data and was used only by Hamad, Azim, and Mazigh.

In example 4.10, we see that another Islamic expression is used, /mafa:?ala:h/ (literally, 'what God has willed'). There is no exact translation equivalent for this phrase in contemporary English. Glosses might range from "My goodness" to "Glory be," but 
both these lack the intensity of the positive valence the phrase carries as well as the explicit encoding of divine will and even intervention. The phrase is used to show "appreciation, joy, praise, or thankfulness" as in example 4.10 (see the Wikipedia entry for $M \bar{a}$ sha' 'Allāh for more information). Here, Hamad expresses his admiration to the new generation of youth who makes good use of technology and computers available to them to promote free speech and free media outside of Gaddafi's control.

Example 4. 10. Hamad [00:19:00-00:20:23]

$\begin{array}{llllll}\text { maja:? } & \text { Pal's } \mathbf{c} \text { :h } & \text { isa.xdam.ant } & \text { i:bu:fi:lan } & \text { aћsa:n } & \text { istixda:m } \\ \text { willing. IMP } & \text { Allah } & \text { use.PAST.it } & \text { youth } & \text { best } & \text { use.N } \\ \text { MSA } & \text { MSA } & \text { T } & \text { T } & \text { MSA/LA } & \text { MSA/LA }\end{array}$
"masha'Allah, the youth have put it [the computer] to the best [possible] use"

The expression /mafa:? ala:h/ was found three times in the data. This and other phrases borrowed from Arabic into Tamazight are shown in Table 4.3 below.

Table 4. 3: Islamic phrases in the data originally borrowed from Arabic into Tamazight

\begin{tabular}{|c|c|c|}
\hline \# of tokens & Transcription & English translation \\
\hline 3 & 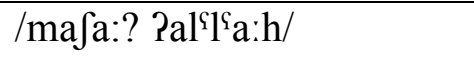 & What God has willed \\
\hline 19 & /infa:? Pal's'sa:h / & God willing \\
\hline 1 & /ra:bi subhanahu wa t9a:la/ & Glory be to the Lord God \\
\hline 2 & /subћæn Pal'l'a:h / & Glory be to Allah \\
\hline 1 & $\begin{array}{l}\text { /bism ila:hi arrahma:n } \\
\text { ærræhi:m/ }\end{array}$ & $\begin{array}{l}\text { In the name of Allah, the Merciful, the } \\
\text { Compassionate }\end{array}$ \\
\hline 1 & /asala:m Sleiknm/ & And peace be upon you \\
\hline 1 & /alha:mdu lil؟a:h/ & Thanks be to Allah, \\
\hline 2 & /Pal'l'a:hu akba:r/ & $\begin{array}{l}\text { Allah is the Greatest (lit., Allah is } \\
\text { greater) }\end{array}$ \\
\hline 1 & /rabi jarha:m a Juhada/ & May Allah have mercy on the martyrs' \\
\hline 1 & /Pal'l'a:h jibarak fi:k/ & May Allah bless you \\
\hline
\end{tabular}




\section{Tamazight Utterances with Core Borrowing}

Core borrowings differ from cultural borrowings in that cultural borrowings fill lexical gaps in the borrowing language and often accompany a new thing or concept that enters the culture and language. Core borrowings, on the other hand, are borrowed items that roughly correspond to elements that already exist in the language doing the borrowing. These borrowings start as foreign elements in the language, and they become integrated in the language's grammatical system. Based on MLF predictions, one can expect core borrowings to appear less frequently than cultural borrowings (cf., 1993: 206), culturally borrowed forms will show an overall high relative frequency and that core borrowed forms will show high frequency compared to CS forms. Examples of the core borrowings in this data are the negation markers $/ \mathrm{mu} /$ and $/ \mathrm{ma}-\mathrm{f} /$ negation marker. As noted above, we are not surprised to find core borrowings involving items that are structural and/or grammatical in nature, that is, items that are seen as being closed-class items.

\section{Code switching (CS) Between Tamazight and Arabic}

In this study, Tamazight and Arabic were expected to vary in terms of their positions and identification as the matrix language (ML) and the embedded language (EL) throughout the data. I began by examining examples where Tamazight is the ML and then moved to examining the Arabic language as the ML in these interactions. For each of these instances, I give two examples to illustrate the case of CS and why Tamazight or Arabic appears as the ML. 


\section{A. Tamazight as the Matrix Language (ML)}

In the utterances examined here, as assumed by the MLF model, Tamazight is the dominant language as its grammar provides the structure for the whole sentence, into which lexical items are inserted from the Arabic language. Table 4.4 below represents the number of Tamazight utterances as the ML in the data. As in Tables 4.1 and 4.2, the data in this table represent utterances in terms of speaker and language. Table 4.4 shows 175 utterances in which Tamazight is the matrix language.

Only three speakers produced mixed phrases and sentences in which Tamazight was the dominant language in terms of grammar and structure. Of the three, Hamad produced the majority of the utterances (117), followed by Azim (44) and Mazigh (14). Other speakers in the data did not contribute to this part of the code switched data.

Because of the amount of time they were given to talk, their speech differed in terms of the number of utterances and use of one language or the other. Given the differences in the broadcast, and the amount of time, and the number of topics he spoke about, it was not surprising that Hamad produced the majority of both pure Arabic and pure Tamazight utterances as well as incidents of CS. Azim was second after Hamad with a total of (58) utterances, then Mazigh with (18) and the girl with only 8 utterances.

Table 4. 4: Tamazight as the Matrix Language (ML)

\begin{tabular}{|l|l|l|l|l|l|l|l|}
\hline $\begin{array}{l}\text { Spoken } \\
\text { Utterances }\end{array}$ & Azim & Hamad & Maizgh & Girl & $\begin{array}{l}\text { Unidentifi } \\
\text { ed voice 1 }\end{array}$ & $\begin{array}{l}\text { Unidentifi } \\
\text { ed voice 2 }\end{array}$ & Total \\
\hline $\begin{array}{l}\text { Utterances in } \\
\text { Arabic }\end{array}$ & 2 & 13 & 0 & 0 & 2 & 0 & 17 \\
\hline $\begin{array}{l}\text { Utterances in } \\
\text { Tamazight }\end{array}$ & 11 & 16 & 3 & 7 & 0 & 1 & 38 \\
\hline $\begin{array}{l}\text { Utterances with } \\
\text { Ar as the ML }\end{array}$ & 1 & 24 & 1 & 1 & 0 & 0 & 27 \\
\hline
\end{tabular}




\begin{tabular}{|l|l|l|l|l|l|l|l|}
\hline $\begin{array}{l}\text { Utterances with } \\
\text { T. as the ML }\end{array}$ & 44 & 117 & 14 & 0 & 0 & 0 & 175 \\
\hline Total Utterances & 58 & 170 & 18 & 8 & 2 & 1 & 257 \\
\hline
\end{tabular}

To illustrate Tamazight as ML, I provide two examples representing cases where Tamazight plays the role of the ML and Arabic as the EL.

\section{Example 4. 11. Hamad [00:03:22-00:03:43]}

t'abYan di:s ti:karkas jerxa of.course this lie.SING clear $\begin{array}{llll}\text { MSA/LA } & T & T & T\end{array}$

"of course this is a clear lie"

In example 4.11, the bold item is the Arabic discourse marker in an otherwise Tamazight sentence. The speaker began with the Arabic adverb /t`abৎan/ "of course," and finished the sentence in Tamazight. This Tamazight sentence includes the demonstrative pronoun /di:s/ "this" which refers cataphorically to the noun/ti:karkas/ "a lie" and the adjective /jerxa/ "clear." This adverb was mentioned three times in the data; two by Hamad and one by Mazigh. Speakers did not use any other equivalent form of the Arabic adverb, which supports that argument that this is a switch instead of a borrowing.

Example 4. 12. Hamad [00:04:03 -00:04:45]

$\begin{array}{llll}\text { i.su:fa:s } & \text { ta:rwa:.nis } & \text { in } & \text { barra: } \\ \text { he.send away. IMP } & \text { child.PL. his. } & \text { to.PREP } & \text { abroad.N } \\ \text { T } & \text { T } & \text { T } & \text { LA } \\ \text { "he (Gaddafi) sends his children abroad" } & & \end{array}$
"he (Gaddafi) sends his children abroad"

Example, 4.12, also presented the Arabic item in bold. Here, the speaker inserted an Arabic item /barra:/ into Tamazight sentence. The sentence consists of Tamazight items such as a singular the prefix represented in the vowel /i/. 
This prefix marks the singular and masculine. It is understood here to refer to Gaddafi, who was the topic of the discussion in this part of the broadcast. Hamad embedded the Arabic word /barra:/ "abroad," instead of using the Tamazight equivalent, /tenere/. The phrase /ta:rwa:nis/ "his children" acts as the object of the verb /i.su:fa:s/ "send," in this sentence. Here, too, the possessive pronoun /nis/ "his" that refers to Gaddafi is attached to the preceding noun /ta:rwa:/ "children" meaning "his children." Thus, the grammatical structure of this sentence is Tamazight with an inserted Arabic adverb.

In examples, 4.11 and 4.12 , the syntactic frame for the sentences is provided by the Tamazight language. These were both examples of intrasentential code switching with Tamazight as the matrix language.

\section{B. Arabic as the Matrix language}

Here, I illustrate examples of Arabic as a matrix language. In these instances, Arabic dominates the structure of the sentence and the number of lexical items in the sentence (although this latter criterion is not the more significant one). Speakers in such instances embedded Tamazight items as they switched from Arabic to Tamazight in their speech.

\begin{tabular}{lll} 
Example & 4. & \multicolumn{2}{c}{ Hamad } & [00:02:42 -00:03:17] \\
ju:mkin & S $^{\text {Sa }}$ & jamat \\
maybe & true & he.die. PAST \\
LA & LA & $\mathrm{T}$
\end{tabular}

"maybe it is true that he died"

In example 4.13, the Tamazight item in the sentence is in bold. Here, we have two CPs: [Maybe it is true $A R$ ] [(that) he $\operatorname{died}_{\mathrm{T}}$ ]. In the first CP, 'maybe' is an adverb, 
modifying 'it is true', [it is] true involves an adjective used in an expletive structure as in 'it is ADJ that'. In the second CP, which is governed by the first, the verb /jamat/ constitutes the entire CP. The first sound of the verb /jamat/ represents the subject, which is third-person singular and masculine. Thus, while this is intrasentential CS, it is not inter-CP code switching.

The second example, 4.14, is representative of the Arabic language acting as the ML. The Tamazight item is marked in bold. In this example, the speaker again used an Arabic structure along with Arabic lexical items and then switched to Tamazight at the end of the sentence. The speaker used the Arabic structure when he uttered the noun /əlharb/ "war" that was modified by the Tamazight adjective /tishal/ "easy" before the adjective. He also used the Arabic negator /muf/ "not" before the adjective. Thus, the subject and the verb of the sentence come from the Arabic language, and the adjective comes from Tamazight. Were the Tamazight negation and structure to be used in this sentence, it would likely read /wot tishal əlharb/, literally, 'not.easy, the war.' (war is not easy).

Example 4. 14. Hamad [00:24:29-00:25:21]

$\begin{array}{lll}\text { əl.ћarb } \quad \text { mu } & \text { tishal } \\ \text { war } & \text { is.NEG } & \text { Easy } \\ \text { LA } & \text { LA } & \text { NB T } \\ \text { "war is not easy" } & \end{array}$

\section{Discourse Marker /ja凡ni/ "I mean"}

Following is a discussion of the discourse marker /jaSni/ "I mean," which was chosen for comment because of its frequent use by all the speakers in the data except for 
the unidentified voices, who did not use it at all. This discourse marker occurs with great frequency in the speech of many speakers of Arabic, and native speakers of Arabic often use it even when speaking other languages. In total, there are 116 tokens of / jaSni / found in the video. The number of tokens per speaker is displayed in Table 4.5 below.

Table 4.5: Occurrences of /jaSni/ "I mean" by speaker

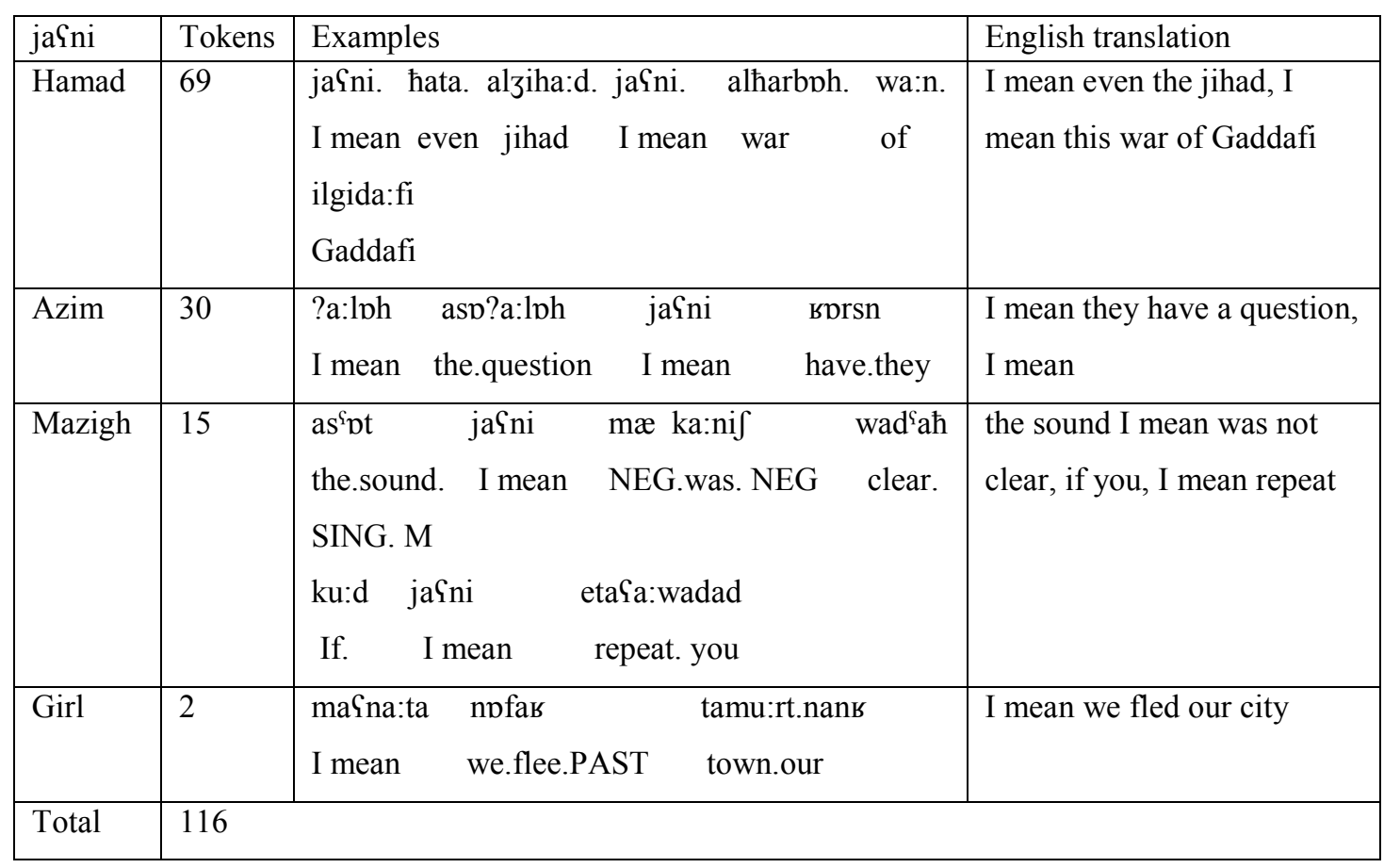

As shown in the examples in the above table, speakers used the discourse marker /jaSni/ or /maSna:ta/, another form of the discourse marker/ja9ni/, as a filler. When speakers used /jaSni/ in a phrase or sentence, they often switched to the other language in the next word or phrase. In other words, speakers use the expression as a floor holder, indicating that they were searching for a word or trying to figure out how to express an idea. The switch is usually from Arabic to Tamazight or to a borrowed Arabic word that is pronounced using Tamazight pronunciation. 
The examples below show the use of/jaSni/ by different speakers:

Example 4. 15. Mazigh [00:14:10-00:18:50]

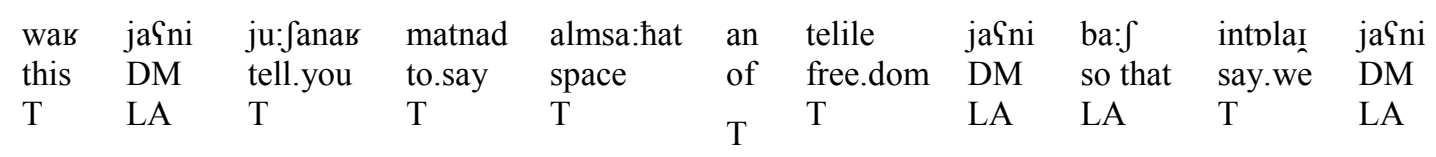

This, I mean, we have a space of freedom, I mean, so that you can say, I mean

The above example shows that the speaker used the discourse marker/jaini/ as a filler, especially at the beginning and at the end of sentences. The examples, also, show us that these speakers switched to the discourse marker/jaSni/, instead of using the the other form that is associated more with the Tamazight-speaking communities in the Nafusa Mountain, i.e. /maSna:ta/.

$\begin{array}{llll}\text { Example } & \text { 4. 16. Girl [00:23:44-00:24:11] } & \\ \text { maSna:ta } & \text { npfas } & \text { ta:mu:rt } & \text { nans } \\ \text { I mean } & \text { we.leave.past } & \text { city } & \text { our } \\ \text { LA } & \mathrm{T} & \mathrm{T} & \mathrm{T}\end{array}$

"I mean we left our city"

In example, 4.16, the young Amazigh girl spoke about the fact that she, her family, and other people in her hometown have had to flee the country into the Tunisian border. In her televised speech, she spoke in Tamazight urging the world to intervene and save them from Gaddafi and his forces. The example shown below demonstrates her particular lexical choice using the discourse marker/maSna:ta/, instead of /jaSni/. While Libyans would be familiar with both forms, the Amazigh associate /maSna:ta/ with Tamazight-speaking communities in the western mountain areas.

Examples 4.15 and 4.16 show cases in which different speakers used the discourse markers /jaSni/ and /ma@na:ta/, which are two different forms of the same discourse marker. The first, /jaSni/, was used by the majority of speakers in the data. 
Example 4.16 shows the girl's lexical choice of /maSna:ta/. Both forms are used by speakers of Arabic and Tamazight not only in Libya, but also in other neighboring countries in North Africa like Tunisia and Algeria.

While the three speakers, Hamad, Azim and Mazigh, used /jaSni/, the girl at the end of the video uses /maSna:ta/ which does not differ in meaning from /jąni/. Here, 116 tokens of /jaSni/ are counted with only two occurrences of /maSna:ta/ specifically uttered by the girl. These occurrences are divided in the data in terms of the number of utterances by each speaker. Hamad, who did most of the talking in the data uttered the largest number of discourse markers (69), then came Azim (30), Mazigh (15) and finally the girl (2). In most of the cases, /jaSni/ was used by the speakers as a filler when switching between the two languages. Moreover, /jaSni/ occurs mostly at the beginning of Arabic phrases and sentences or at the end of these sentence just before switching to Tamazight. Examples 4.15 and 4.16 in the data show such cases.

As someone who code switches between Arabic and Tamahaq and for whom Arabic is my stronger language, I hypothesize that these speakers often use /ja9ni/ when thinking about the right or correct Tamazight words to use or to hold the floor for an appropriate switch into Tamazight.

Whereas the discourse marker, /ja9ni/ occurred 116 in the spoke data, there were no occurrences of it in the read-aloud data. As Ochs (1979) defined it, "Planned discourse is another kind of discourse that has been thought out and organized prior to its expression." The read aloud data are considered to be carefully planned, and therefore, it is no surprise that we do not find any discourse markers within them. 


\section{The Read-Aloud Data}

The other type of data represented in the broadcast is read aloud data. This was a set of news reports read aloud by reporters. Azim, the anchor, introduces the news headlines, and then someone else read aloud a news report on one of the topics discussed in the broadcast. These news stories were accompanied by a video report on the topic. The data consisted of three short news reports read by people who were not shown on TV. There were also three lines of read-aloud data that appear on the screen that were uttered by Azim when he started the first news story.

Following is a discussion of the read aloud data set. Here, I argue that the nature of these data is different from that of the spoken data. Obviously, these data are characterized by more careful and explicit planning and organization in terms of the Tamazight language that was used than the spoken data. This could help account for why there were very few instances of CS in this data set, since most of the CS instances in the entire data set were intrasentential and occur in the data discussed above. The tables and the examples in this section are intended to show cases of Arabic items in the data. Unlike the spoken data, the read aloud data set was, for the most part, Tamazight.

There were significantly fewer tokens of Arabic grammatical items than in the spoken data. Table 4.6 below represents the number of the Arabic grammatical items in this data set. Only nouns and adjectives from Arabic are found in these data. As in the spoken data, the Arabic items found in this category are a mix of fus ${ }^{\mathrm{h}}$ ha (MSA) and Libyan Arabic (LA). 
Table 4. 6: Number of Arabic items in the read aloud data

\begin{tabular}{|l|l|l|l|l|}
\hline Category & $\begin{array}{l}\text { \# of } \\
\text { tokens }\end{array}$ & Examples & Transcription & English translation \\
\hline Noun & 21 & الشهداء & /aS.fuha:da/ & the martyrs \\
\hline Adjective & 2 & لاحرة & /al.hu:rra/ & the free \\
\hline Total & 23 \\
\hline
\end{tabular}

Usages like "the free" in Table 4.6 are new to the Libyan context. During the war, people in some towns and cities that became free from the control of the Gaddafi forces started to call their cities and town "the free", (e.g. Jado, the free), as in contrast to those nearby cities and/ or towns under the control of Gaddafi's forces.

Other examples of Arabic items from the table are shown in the following examples. The Arabic forms are boldfaced. Example 4.17 contains numbers and a noun while Example 4.18 contains a noun.

Example 4. 17. Shukri, news reader [00:06:23-00:07:40]

$\begin{array}{llllll}\text { in } & \text { tisfa } & \text { u } & \text { Gifri:n } & \text { n.igraovli:n } & \text { a f. fuha:da? } \\ \text { of } & \text { nine } & \text { and } & \text { Twenty } & \text { of. revolutionary.PL } & \text { DEF.martyr.PL } \\ \text { T } & \text { LA } & \text { LA } & \text { LA } & \text { T } & \text { MSA } \\ \text { "twenty-nine martyrs of the revolution" or "twenty-nine revolutionary-martyrs" }\end{array}$

"twenty-nine martyrs of the revolution" or "twenty-nine revolutionary-martyrs"

Example 4. 18. Shukri, news reader [00:06:23-00:07:40]

$\begin{array}{lll}\text { dis } & \text { al.intifa }: \mathrm{d}^{\mathrm{C}} \mathrm{a} & \text { tagravila } \\ \text { this } & \text { the.intifada } & \text { revolution } \\ \mathrm{T} & \text { LA } & \mathrm{T}\end{array}$

"this is the intifada revolution"

Example 4.19 is an example of an adjective. The adjective is feminine because, as in Arabic, place names in Tamazight are grammatically feminine regardless of their morphological shape. 
Example 4. 19. Shukri, news reader [00:12:22-00:14:10]

$\begin{array}{lll}\text { du:ha } & \text { za:dp } & \text { hu:rra } \\ \text { now } & \text { Jado } & \text { free.SING. F } \\ \text { T } & \text { PN } & \text { MSA/LA } \\ \text { "Now Jado [a city], is free" }\end{array}$

From Table 4.6 and the examples above, we can conclude that there are far fewer occurrences of Arabic items such as nouns and adjectives in this data as compared to the spoken data. Additionally, we notice the absence of other grammatical categories such as verb and adverb.

The last category that appears in both the spoken and the read-aloud language data is Arabic numbers. In the spoken data, there are a few instances in which speakers use Tamazight numbers in addition to the Arabic ones. In contrast, in the read-aloud data, there are no occurrences of Tamazight numbers. All numbers found in this data are read aloud as purely Arabic. The numbers found in this data represent either the number of those killed by the Gaddafi forces, how old Gaddafi's son is, or a reference to the February 17, 2011 uprising. In all of those contexts, speakers use Arabic instead of Tamazight numbers. Tokens of these numbers are shown in Table 4.7 below.

Table 4. 7: Tokens and examples of Arabic numbers in the Read-Aloud Data

\begin{tabular}{|c|c|c|c|}
\hline Number & Tokens & Transcription & English translation \\
\hline 29 & 3 & $\begin{array}{l}\text { in tisha } u \quad \text { Gifri:n nigraojli:n } \\
\text { of. nine and twenty martyrs. T } \\
\text { martyrs.Ar }\end{array}$ & $\begin{array}{l}\text { twenty nine martyrs of } \\
\text { the revolutionary }\end{array}$ \\
\hline 17 & 2 & $\begin{array}{lr}\text { sa:bGt }{ }^{\mathrm{s}}: \int & \text { fubrra:jar } \\
\text { seventeenth } & \text { february }\end{array}$ & February $17^{\text {th }}$ \\
\hline 7 & 1 & $\begin{array}{lll}\text { da:fru:x } & \text { nig } & \text { sa:bৎa } \\
\text { son.SING.M } & \text { of } & \text { seven }\end{array}$ & The seventh son \\
\hline Total & 6 & & \\
\hline
\end{tabular}


As can be seen from the examples in the Table 4.7, the speaker used both cardinal and ordinal Arabic numbers. As noted earlier, Tamazight numbers are completely absent in this data set in contrast to the spoken data where a few occurrences were found. In this case, I would make two observations. First, I hypothesize that because of the education system in Libya, the participants in this data have considerable experience reading Arabic aloud but have very little, if any real, experience reading Tamazight aloud. Therefore, they might not be familiar with reading the Tamazight numbers aloud and would prefer the Arabic numbers instead, perhaps falling back on them as default. Second, younger generations nowadays generally do not use or know Tamazight numbers beyond 10 or so. Thus, these readers may or may not have known these numbers, but they could have correctly assumed that the majority of the audience would not have understood them and thus used Arabic numbers instead.

Likely because of the similarities between the two languages and their history of contact, there were no problematic cases found that require the application of the 4-M Model. As pointed out in Chapter 2, both Arabic and Tamazight are Afro-Asiatic languages. Their typology is similar, and they have been in contact for a long period of time. This similarity and long-time contact has likely brought the two languages much closer to each other.

Here, I hypothesize that the relationship between Arabic and Tamazight is similar to that of the Modern Standard Arabic and the spoken Arabic dialect, where over time, each variety has influenced the other. In saying that, I do not mean to imply that diglossia no longer exists or that switching between the two varieties of Arabic is unproblematic 
with regards to the 4M model, a topic investigated in detail by Boussofara-Omar (1999, 2003a, 2003b, 2005). Instead, I argue that the relationship between the two languages is a give and take, rather than one only language borrows while the other only lends. In fact, this long-term contact helps account for the ways that North African Arabic differs from varieties to the East. The MLF (Myers-Scotton, 1993) Model takes care of the cases of CS we have seen between the two languages, Tamazight and Arabic, in these data; thus, there was no need to invoke the more detailed (and powerful) 4M model.

\section{Answering the Research Questions}

Having analyzed the use of Tamazight and Arabic in the data, I can now provide an answer to the research questions.

\section{Research Question One}

What was the nature of the code-switching between Tamazight and Arabic in the linguistic choices the Amazigh interlocutors made on TV in light of Myers-Scotton Matrix Frame Model (MLF) (Myers-Scotton, 1993) and the 4-M model of code switching (Myers-Scotton \& Jake, 2000)?

In response to the first research question, the results showed that both languages sometimes served as ML and sometimes as EL. Generally, Tamazight was the ML, and Arabic was the EL. Also, Arabic was the source of many content morphemes, as well as other grammatical categories such as the discourse markers and religious phrases and expressions.

As shown in Table 4.1, the total number of intra/intersentential switches is 241, 221 of which were classified as intrasentential and only 20 classified as intersentential. 
The majority of switches occur within the same phrase or sentence where speakers inserted items from Arabic or Tamazight phrase or sentence. The other type occurred when speakers uttered a complete phrase or sentence in a given language and then changed to the other language in the next phrase or sentence. In this type of occurrences, sometimes speakers would alternate between pure and borrowed items in the other language as they switch.

Also as shown in Table 4.1, in the switches in the spoken data, Tamazight was the ML for 175 phrases and sentences out of 257 total utterances (of which 202 involved CS), the clear majority of the utterances. The switches in these data included content words such as nouns, verbs, adjectives and adverbs. Proper nouns were not considered either as switches or as borrowings because they do not change when used by the speakers of the other language. Switches occurred between both Tamazight and MSA and between Tamazight and LA. As shown in some examples in the data, by switching to MSA, speakers made their speech seem to be more formal because MSA is believed by many speakers of Arabic to be more appropriate variety to use when talking about certain topics in a TV setting, such as religion. It is worth mentioning here that not all speakers used MSA as they switched from Tamazight to Arabic. Instead, they also switched to Libyan Arabic.

Speakers may have also switched to LA since it is the variety that everyone speaks in Libya and may be easier to get their message through to their Libyan audience, who, in addition to being Tamazight speakers, were also speakers of Libyan Arabic. The use of LA might have also served as a secure refuge for the participants in the data to 
switch to comfortably whenever they did not have a ready equivalent of Tamazight words or expressions present to use.

Most likely, for the participants in this video data, Arabic is considered a linguistic safe haven. These speakers are highly fluent bilinguals in both languages. Second, Arabic is their dominant language in many regards as it is the language of their education. This TV setting is a novel discourse or rhetorical context $-\mathrm{a}$ formal and public one. Therefore, it is not surprising that these speakers often relied on Arabic in cases where there is a lexical gap in Tamazight; where they were searching for a Tamazight word or expression, or where Arabic expressed a concept more effectively.

The relationship between the two languages and what role each language played in the interaction was shown in the nature and tokens of the switches. In these data, I found examples that are consistent with Myers-Scotton's findings, where language choice is made as phrases and sentences are constructed.

With regard to the news reports that were read by people off camera, they were mostly in Tamazight, but speakers inserted Arabic items such as nouns and adjectives into their speech.

Thus, with regard to research question one; it is clear that Myers-Scotton's model can account for the types of CS in the data with no problematic cases that the model cannot handle. The importance the 4-M model of CS in this study is to facilitate the recognition and classification of the relationship between the two languages. Two types of CS are apparent in the data: intersentential and intrasentential switches. These types of 
switches inform us what role each language has played in the data and for what purposes speakers exploited their linguistic resources within the exchanges.

Tamazight was the native language of the speakers, and it often supplied the syntactic structure as well as system morphemes and many content morphemes. Despite the differences between the two sets of data in terms of the nature of the CS that took places, the CSs were similar in terms of the role each of the two languages played in the overall interaction. In contrast to the spoken data, where both languages served as ML, and EL, in the read-aloud data, system morphemes such as singular and plural markers, possessives, and gender markers were supplied by Tamazight (ML), while Arabic played the role of the EL, which provided the content morphemes to which many of those system morphemes were attached.

\section{Research Question Two}

What influence does Arabic have over the post February 17, 2011, Tamazight language in a TV setting as represented by the Tamazight speakers?

This question looks at the relationship between the two languages in the public space. It also looks at the effects of Arabic on the Tamazight languages used by Tamazight speakers in a TV setting - a formal setting. In this language contact situation, the question examines what role one language, Arabic, might play with regard to the other language, Tamazight, the language in which the entire program might have been expected to take place in since the program advertised itself as the first Libyan news broadcast in Tamazight. 
The data analysis of the nature and types of intrasentential and intersentential switches revealed the relationship between the two languages. It also showed what influence Arabic had over the post-February 17 Tamazight language in this broadcast. As seen from the analysis, the majority of switches took place within the sentences (intrasentential). The majority of these were Arabic items inserted within the Tamazight sentence. Arabic often played the role of the EL, supplying content morphemes. These content morphemes come in the form both single words such as nouns, verbs, and adjectives and phrases. Arabic's role is also seen in providing religious phrases, fixed expressions, and terms of address used in the data and used by all speakers of Tamazight. Moreover, other items such as prepositions, discourse markers, numbers also come from the Arabic language in most cases. Additionally, with regard to the spoken data, certain utterances $(\mathrm{n}=17)$ were entirely in Arabic, fewer than half the utterances that were entirely in Tamazight ( $\mathrm{n}=38)$, and code switched utterances in which Arabic served as ML ( $\mathrm{n}=27$ ) accounted for only $13 \%$ of the utterance in which code switching occurred. Arabic served a number of functions in the broadcast. Those functions included discourse markers, numbers, scaffolding, religious expressions and affectively loaded terms. In terms of the discourse marker/jaSni/ and scaffolding, both were expressed in Arabic as /jaSni/. With regard to /jaSni/, there are two forms of this particular discourse marker, /jaSni/ and /maSa:nta/. Three speakers in the spoken data used /jaSni/, and only one speaker, the young girl, used the other form, /maYa:nta/. Scaffolding in both sets of data was generally provided in Arabic. Ordinal numbers such as first and second were 
used in Arabic to scaffold information by participants Azim and Hamad. Numbers in the read-aloud data set were used as well for the same scaffolding purposes.

Arabic numbers were found in both data sets. In the spoken data, they were found in both ordinal and cardinal forms, whereas in the read-aloud data, they were found in the cardinal form only. Tamazight numbers, on the other hand, were only found in the spoken data as ordinals. They were not found in the read-aloud data in any form.

All the religious expression came from the Arabic language as well. Some of those expressions were in MSA and other were in LA. Speakers used the Arabic Islamic expressions although sometimes those expressions had Tamazight equivalents. For Muslims, the use of Arabic religious expressions is meant either to show respect, as in the case of referring to a deceased individual, or just the fact that certain topics like religion when discussed in a TV setting, they are talked about dealt with in Arabic.

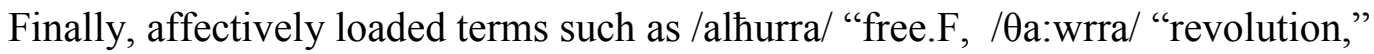
and /af.Juha:da/ "the martyrs" were mostly in Arabic. Prior to the revolution, speakers of Tamazight would not have used such terms in Tamazight as it would be considered a politicized violation of the political code of the Gaddafi era — if speaking Tamazight was dangerous, talking about politics in Tamazight was even more dangerous. These terms are significantly charged in Arabic and would have had a strong effect on the hearers.

Likely because of the similarities between the two languages, there were no problematic cases found that require the application of the 4-M Model. As pointed out in Chapter 2, both Arabic and Tamazight are Afro-Asiatic languages. Their typology is 
similar, and they have been in contact for a long period of time. This similarity and longtime contact seemed to bring the two languages much closer to each other.

In conclusion, this chapter examined the nature of CS between Tamazight and Arabic in the first Libyan Berber news broadcast during and after the uprising against Gaddafi in 2011. The chapter focused on the data analysis in the light of Myers-Scotton's 4M model of CS. The chapter began with an overview and then presented utterances from the data by speaker and language in Table 4.1. The languages in the data were divided into Arabic and Tamazight, as well as the occurrences CS between the two languages.

The Arabic language data consisted of Modern Standard Arabic (MSA), Libyan Arabic (LA) and diglossic switching between the two varieties of Arabic. Throughout the analysis, I gave examples of the various types of the Arabic language from the data. Those examples showed cases in which speakers only used the Arabic language in the interactions or in the read aloud data

The Tamazight language data set consisted of purely Tamazight utterances and Tamazight utterances with cultural borrowing and a single core borrowing, which are mostly religious as well as core borrowings. Examples from the data were given for each of the above cases. This chapter also covered a discussion of the discourse marker /jaSni/ "I mean." This particular discourse marker was used by almost all speakers in the data, except for the unidentified male voices.

The chapter concluded by offering responses to each of the research questions. 
Chapter 5

Conclusion

This chapter has four main goals. First, it seeks to summarize the finding of the results chapter; second, it discusses the limitations of this study; third, it highlights some implications of this research for the fields of linguistics and sociolinguistics as well as the study of code switching; and, finally, the last section of the chapter provides suggestions for further research on the specific topic of the thesis.

The post Feb. $17^{\text {th }}$ linguistic situation in Libya is certainly more diverse with the emergence of newer language varieties in the Libyan media and public sphere (Abdulaziz, 2012a, 2012b,) than it was during the Gaddafi era. With the emergence of Tamazight and Tamahaq in the media, including radio and television as well as written media - newspapers, magazines, the Internet and public street art, the Libyan linguistic landscape is more diverse than it used to be. Arabic and Tamazight now have new roles in the society such as redefining and representing a collective Libyan identity. For all Libyans, Arabic is not only a language but also a source of pride and an essential component of their national and religious identities. For a long time, Libyans have known no other language as a language of education, media, official use, and the common language of communication with others in Libya. For these reasons, in situations where code switching occurs, Arabic is a supplier of content morphemes, religious phrases, greetings, and fixed expressions as illustrated by these data. We can assume, however, that we would observe similar functions for Arabic were two Libyans in a situation where they spoke primarily English to one another; in other words, Arabic would continue to fill 
these functions, evidence of the role of Arabic in Libyan identity. The relationship between Arabic and varieties of Berber is a subject of debate within the Libyan decisionmaking circles at the highest levels of the state, within the Amazigh and Tuaregs communities, as well as among the Libyan Arabs. It is my contention that this unsettled relationship will remain for many years to come as it is now. This belief comes from the fact that many Libyan Amazigh, especially those living in Tripoli, are more fluent in Arabic than Tamazight. With the political changes sweeping across the Middle East and North Africa, language issue remains in the heart of those events, especially in Libya, Algeria and Morocco. This language debate is shaped by other related political debates on the question of Berber rights - political and linguistic — as well as the question of identity of Berbers across North Africa (Weitzman, 2011, 2012).

As discussed in chapters 3 and 4, the data for this study were divided into spoken and read-aloud data sets. Within these data sets, there was a Pure Arabic data set, which consisted of Modern Standard Arabic (MSA), Libyan Arabic (LA), and diglossic switching between MSA and LA. There was also a Pure Tamazight data set. This data set included purely Tamazight utterances, Tamazight utterances with cultural and core borrowings. Cultural borrowings related mostly to religion. Core borrowings were rarer than cultural borrowing, but examples of those are negation markers such as the circumfix used to negate verbs /ma- $\int /$.

The types of switches seen in these data agree with Myers-Scotton MLF model (1993) and the findings of earlier research on CS. In the spoken data, both languages play the role of both the ML and EL. Additionally, whenever we find the ML, it is the main 
supplier of structure and system morphemes whereas the EL provides content morphemes speakers need to communicate their message, which they sometimes cannot effectively do in the ML.

With regard to numbers, Arabic was the main source of the majority of the numbers in the data and the unique source for numbers in the read-aloud data. Arabic numbers came both in the ordinal and cardinal forms whereas in Tamazight, there were only 5 tokens of cardinal numbers such as /tu:ha u:zut/ "this is first." Overall, 25 occurrences of Arabic numbers are found in this data set. Arabic negations are more common in the data than Tamazight negations.

In response to the first research question, both languages served as (ML) and (EL). In this data, Tamazight was generally the (ML), and Arabic the (EL) providing most of the content morphemes. Speakers switched between Tamazight and Modern Standard Arabic as well as between Tamazight and Libyan Arabic. The read-aloud news reports were generally in Tamazight with Arabic items inserted within the Tamazight sentences and phrases. Myers-Scotton's MLF model accounts for the code switching between the two languages with no problematic cases that the model could not handle. In answering the second research question, the study found that there were two types of code switching within the data: intrasentential and intersentential switches. The majority of the switches that took place in this data were the intrasentential, in which Arabic items were inserted in the Tamazight sentences and CPs. Also, in this type of the switching, Arabic often played the role of the EL supplying content morphemes as well 
as supplying religious phrases. In the other type of switching, the intersentential, speakers completely switched from one language to the other.

As a Tuareg, a member of an ethnic and linguistic minority in Libya, and a speaker of Tamahaq, the language spoken by the Tuareg, I'm proud to witness these changes taking place in my country. They stand as evidence of advances for minorities in terms of their linguistic and cultural rights. I hope this thesis will be a good addition and a positive contribution to the national dialogue on the linguistic rights of all Libyans. Also, by analyzing this first broadcast, I hope that it sparks further national discussion on a different level looking at the functions and use of both languages in the Libyan daily life as well as in the media, education and government.

As someone who lived most of my life under the Gaddafi regime and witnessed many changes in the language policies of Libya throughout the years, I am hopeful and optimistic that the future will be brighter for all Libyans. I believe that the upcoming Libyan constitution will lay out a clear language policy where all citizens have the right to use their language and be proud of their language, culture and history.

On the academic side, I have hopes that this thesis will not be the last academic work on the phenomena of language contact among different languages in a Libyan setting. My hope is that more research will be carried out to understand the nature of those phenomena. I'm also positive that Libyan academic society is eager to see more research conducted on issues of language policy, language planning, and education. As I note elsewhere in this thesis, more research is needed in the field of linguistics in general and sociolinguistics in particular. It is time for Libyan linguists to take part in the bigger 
linguistic dialogues nationally and internationally on a wider scale and play active roles in language issues. Hopefully, this thesis will help instigate investigations into more issues of language policy.

\section{Limitations of this Study}

In this section, I discuss some of the factors that I consider to be limitations in this thesis. The first shortcoming of this study is that, although I am a speaker of a Berber language, Tamahaq, it is a southern Berber variety, which is close to, but not identical with, the northern Tamazight varieties. Though there is a high degree of mutual intelligibility, Tamazight and Tamahaq are usually considered different languages. Even so, I was able to understand much of the conversation because of my proficiency in Tamahaq and Libyan Arabic. However, I asked fluent speakers of the Tamazight dialect, Adel Al Haji and Nabil Abdulrahman, for help with the transcription. Their support helped me understand some cultural and linguistic aspects of the northern Tamazight culture and dialects that I would have otherwise missed.

Another factor that should be addressed is the sample size. This paper looks at the speech of primarily two speakers in the Libyan Amazigh populations. The features we see in this paper can reasonably be attributed to these speakers, but may not be necessarily applicable to other speakers of Tamazight in Libya since the two speakers are from the same speech community - the Nafusa Mountain area - and there are a number of other dialects across the country. Additionally, the amount of data was quite limited. Because I looked at only 25 minutes from one episode of the broadcast, it is not reasonable to make generalizations at this point on whether the linguistic behavior of the 
interlocutors in this video could be transferable to a wider population or due to personal reasons and individual degrees of fluency in this matter.

Although I had hoped to be able to interview the primary speakers in this broadcast, I was unable to do so. Although I tried to contact them, but I did not receive any responses. Getting the speakers' perspective might have helped me better comprehend their understanding of their motivations for the code switching that occurred and whether or not they were aware to the fact that they were switching back and forth between Tamazight and Arabic. Such information might also give us some insight to the preparations they made for the broadcast, for example, whether they discussed what kind of language they should be using or not and how they viewed the language they had used after the broadcast was completed.

Additionally, I did not consider the audience's reaction. It might be very helpful to know what the audience's reaction was to the language used in this first broadcast and how they felt about it. The audience's reaction towards the first episode might have played a role in the language used in the broadcasts that have followed. 


\section{Application / Implications}

In this section, I present the possible implications this thesis brings into the wider areas of linguistic/sociolinguistic research, especially the contribution it makes to the ongoing conversations and arguments about code switching.

This research sheds light on the complex relationship between Tamazight and Arabic in Libya, especially for bilingual speakers of the two languages. Moreover, this study focuses on the role of Libyan Tamazight in the media and what implications it might have for other Amazigh societies, including the Tuaregs, in Libya and in North Africa in general. In a broader sense, this research addresses the longer lasting effects of language policies on indigenous populations and their first languages. It is possible that further research into the revitalization of the Berber languages in Libya could provide insights into, or even roadmaps for, other countries' development of more accepting and inclusive language policies.

This research adds a new perspective to many other studies on code switching between Arabic and other languages, and between varieties of Arabic in other places in North Africa like Tunisia (Boussofara-Omar, 1999, 2003a, 2003b; Walters, 1996, 2003) by looking at the Libyan context. This study also demonstrates how the language of Islam or religion more broadly has had an enduring effect on multiple cultures and on tendencies for code switching and borrowing. 


\section{Suggestion for Future Research}

Here, I make suggestion for future research in the field of sociolinguistic research with regard to the Libyan context and the developing situation of language change and emerging multilingualism there.

The topic of CS between Tamazight and Arabic in the Libyan context in public sphere is a current phenomenon that is still emerging and forming at the same time as public debate about language policy and the position of each language, which is to be determined by the forthcoming constitution. The phenomenon of contact between the two language in this specific context and the settings in which is taking place are understudied for many reasons, including the political and security instability in the country and researchers, especially non-Libyan linguists, not having access to the research tools and resources that might make it possible to conduct linguistic research at this point of Libya's history. Furthermore, Libyan linguists and linguistics students are usually more interested in research in the field of teaching English as a foreign language — politically safer and immediately practical topics - instead of sociolinguistic research on how languages interact inside Libyan society.

Therefore, more sociolinguistic research is needed in order for us to understand what functions each language serves in the society, formally and informally—in everyday communication and use. Further research is also needed to understand speakers' motivations for switching from one language to another in certain settings and what triggers those switches, especially between Arabic and Tamazight. Research here should 
focus not only on TV but also on other forms of media like radio, newspapers and magazines as well as street and shop signs.

Other sociolinguistic research in areas like bilingualism and multilingualism as well as code switching between the languages involved is needed; this kind of research can be done through analysing the linguistic landscape in the post-Gaddafi era as well as analysing other forms of public expression such as street art to determine what is being communicated, by whom, to whom, and what kind of messages and debated being discussed and exchanged on public space (cf Abdulaziz, 2012a).

Sociolinguistic studies would also prove useful in efforts to preserve minority languages such as Tamazight, Tamahaq and Tebu and ensure that they have a place on the future Libyan linguistic map.

Finally, it would also be useful for linguists to conduct research to compare other later broadcasts to this first one to in order to determine if there are changes in the patterns of CS in the speech of bilingual Berber speakers in a TV setting. This will also help us understand whether or not the nature of CS between Arabic and Tamazight has changed. 


\section{References}

Abdulaziz, A. (2012a). The emergence of new forms of Libyan public expression: Street art in Tripoli. Paper presented at the Jil Jadid conference for Arabic studies at UT Austin, TX, February.

Abdulaziz, A. (2012b,). The first Libyan news broadcast in Tamazight: Examining the consequences of Libya's past language policies. Paper presented at the annual conference of the American Institute for Maghrib Studies (AIMS), "Berber Societies: New Approaches to Space, Time, and Social Process.” Tangier American Legation Institute for Moroccan Studies (TALIM), Tangier, Morocco, June.

Arabic language. (2012). In Encyclopedia Britannica Online. Retrieved from http:/www.britannica.com/EBchecked/topic/31677/Arabic-language

Ayahn, V. (2011). Post-Gaddafi period in Libya. IRST Anatolia Daily. Retrieved from http://www.anatoliadaily.com/irst/index.php/authors/4-all-articles-of-veyselayhans-/284-post-gaddafi-period-in-libya

Badawi, El-Said. (1973). Mustawayat al-arabiyya l-mu'assira fi misr. Cairo: Dar al-Ma'arif.

Boussofara-Omar, N. (1999). Arabic diglossic switching in Tunisia: An application of Myers-Scotton's MLF model. (Unpublished Ph.D. Dissertation). University of Texas at Austin.

Boussofara-Omar, N. (2003a). Revisiting Arabic diglossic switching in light of the MLF model and its sub-models: The 4-M model and the Abstract Level model. Bilingualism: Language and Cognition, 6(1), 33-46. doi:10.1017/S1366728903001032

Boussofara-Omar, N. (2003b). Neither third language nor middle varieties but diglossic switching. Journal of Arabic linguistics, 45, 55-80. 
Boussofara-Omar, N. (2005). Political transition, linguistic shift: How a political communiqué (bayaan) has come to be what it is. Amsterdam studies in the theory and history of linguistic science. Series IV, Current issues in linguistic theory, 267, $195-224$.

Dupree, L. (1958). The non-Arab ethnic groups of Libya. Middle East Journal, 12(1), 3344.

El-Kikhia, M. O. (1997). Libya's Qaddafi: The politics of contradiction. Gainesville: University Press of Florida.

Ethnologue (2006). Arabic, Libyan Spoken. Retrieved: from: http://www.ethnologue.com/language/ayl

Ethnologue (2013). Berber language. Retrieved from: https://www.ethnologue.com/subgroups/berber

Ferguson, C. (1959a). Diglossia. Word, 15, 325-340.

Ferguson, C. (1963). The emphatic $l$ in Arabic. Language, 9, 446-452.

Ghadames - The pearl of the desert. In The Tripoli Post (October, 2007). Retrieved from http://www.tripolipost.com/articledetail.asp?c=4\&i=610

Goodman, J. E. (2005). Berber culture on the world stage: From village to video. Bloomington: Indiana University Press.

Golino, F. R. (1970). Patterns of Libyan identity. Middle East Journal, 24(3), 338-352. Harris, L. C. (1986). Libya: Qadhafi's revolution and the modern state. Westview Press. Joffé, G. (2001). Libya and Europe. The Journal of North African Studies, 6(4), 75-92. Marozzi, Justin. (2011) Reprisals against Libyan Tuareg who supported Gaddafi. BBC News Magazine. (September, 17). Retrieved from http://www.bbc.co.uk/news/magazine-14948319

Kohl, I. (2009). Beautiful modern nomads: Border crossing Tuareg between Niger, Algeria and Libya. The Journal of North African Studies. 16(2). doi: 10.1080/13629387.2010.510636.

Kohl, I., \& Fischer, A. (2010). Tuareg society within a globalized world Saharan life in transition. London: I.B. Tauris. 
Libya (2013). In CIA's world Factbook. Retrieved from

https://www.cia.gov/library/publications/the-world-factbook/geos/ly.html

Maddy-Weitzman, Bruce. (2011). The Berber awakening. American Interest, 6 (5.), 29.

Maddy-Weitzman, Bruce (2011). The Berber identity movement and the challenge to

North African states. Austin, TX: University of Texas Press.

http://wals.info/chapter/141

Marçais, P. et al. (1955). Peoples and cultures of North Africa. Annals of the American Academy of Political and Social Science, 298, 21-29.

Masha'Allah. (n.d). Wikipedia. Retrieved December 27, 2013, from http://en.wikipedia.org/wiki/Masha\%27allah

Myers-Scotton, C. (1993). Duelling languages: Grammatical structure in code switching. Oxford University Press.

Myers-Scotton, C. (2002). Contact linguistics: Bilingual encounters and grammatical outcomes. Oxford: Oxford University Press.

Myers-Scotton, C. (2006). Multiple voices: An introduction to bilingualism. Malden, MA: Blackwell.

Myers-Scotton, C., \& Jake, J. L. (2000). Testing the 4-M model: An introduction. International journal of bilingualism, 4(1), 1-8. Retrieved from http://ijb.sagepub.com/content/4/1/1.short

Namba, K. (2002). An overview of Myers-Scotton's Matrix Language Frame model. Tokai University Shimizu www sisf, 1-10. Retrieved from: http://yayoi.senri.ed.jp/research/re09/namba.pdf

National Report of Libya (2008) (n.a). Retrieved from: http://www.unesco.org/fileadmin/ multimedia/institutes/uil/confintea/pdf/national_reports/arab\%20states/ibya_en.pdf

Nisan, M. (2002). Minorities in the Middle East: A history of struggle and self-expression. Jefferson, N.C: McFarland \& Co.

Nisan, M. (2011). Language, memory and identity in the Middle East: The case for Lebanon. Middle East Quarterly, 18, 2. 
Ochs, E. (1979). Planned and unplanned discourse. In Givon, T. (Ed.), Syntax and semantics, vol. 12: Discourse and syntax, New York: Academic Press., 51-80. Page young Tuareg in Libya on Facebook (2011, June, 13). Message and appeal of the Touareg in Libya to abandon the dictator Gaddafi [Video File] Retrieved from: http://www.youtube.com/watch?v=5USroOnHEW0

Pan, C.-L. (1949). The population of Libya. Population Studies, 3(1), 100-125.

Sawani, Y. (2012) Post-Qadhafi Libya: Interactive dynamics and the political future. Contemporary Arab Affairs, 5(1), 1-26, DOI: 10.1080/17550912.2012.650007

The development of education national report of Libya (2008). Paper presented to the International Conference on Education session 48. Geneva. Retrieved from http://www.ibe.unesco.org/National_Reports/ICE_2008/libya_NR08.pdf

The Libyan national report on adult learning and literacy education (2010). UNESCO. Retrieved from http://www.unesco.org/pv_obj_cache/pv_obj_id_9AB52355023C4B71F35F0BF5 760A7EAC381F0700/filename/libya_en.pdf

U.S. Department of State. Bureau of Democracy, Human Rights and Labor. (2012). Country reports on human rights practices: Libya. Retrieved from http://www.state.gov/j/drl/rls/hrrpt/humanrightsreport/index.htm?year=2012\&dlid $=204373$

Vanderwalle, D. (1998). Libya since independence: Oil and state-building. New York: IB Tauris.

Walters, K. (1996). Diglossia, linguistic variation, and language change in Arabic. In M. Eid (Ed.). Perspectives on Arabic linguistics VIII, (pp. 157-197). Amsterdam \& Philadelphia: John Benjamins.

Walters, K. (2003). Fergie's prescience: The changing nature of diglossia in Tunisia. International Journal of the Sociology of Language, 163, 77-109. doi:10.1515/ijsl.2003.048

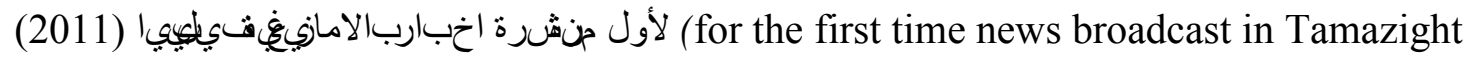
in Libya). Retrieved from: http://www.youtube.com/watch?v=J_-mghWgS2k 


\section{Appendix \\ A Summary of the News Broadcast Video}

\begin{tabular}{|c|c|c|}
\hline Time & Speaker & Topic \\
\hline $\begin{array}{l}00: 00: 00- \\
00: 00: 25\end{array}$ & Azim & $\begin{array}{l}\text { Introduces the first news-story about the killing of Gaddafi's son Saif Al- } \\
\text { Arab and Gaddafi's grandchildren in a NATO raid on their residence in } \\
\text { Tripoli. }\end{array}$ \\
\hline $\begin{array}{l}00: 00: 25- \\
00: 00: 13\end{array}$ & Sanaa & $\begin{array}{l}\text { Read aloud a report about the attacks of Gaddafi's supporters on the } \\
\text { American and European diplomatic missions, as well as the death of } \\
\text { Gaddafi's son Saif-Al-Arab and Gaddafi's grandchildren. }\end{array}$ \\
\hline $\begin{array}{l}00: 02: 15- \\
00: 02: 20\end{array}$ & Azim & Introduces Hamad Bin Khalifa. \\
\hline $\begin{array}{l}00: 02: 21- \\
00: 02: 34\end{array}$ & Hamad & Greets Azim and makes a very brief introduction. \\
\hline $\begin{array}{l}00: 02: 35- \\
00: 02: 41\end{array}$ & Azim & Azim asks Hamad to talk about the news of the death of Saif Al-Arab. \\
\hline $\begin{array}{l}00: 02: 42- \\
00: 03: 17\end{array}$ & Hamad & Talks about the death of Saif Al-Arab and Gaddafi's grandchildren. \\
\hline $\begin{array}{l}00: 03: 18- \\
00: 03: 21\end{array}$ & Azim & Makes a clarification about Gaddafi's grandchildren. \\
\hline $\begin{array}{l}00: 03: 22- \\
00: 03: 43\end{array}$ & Hamad & Answers saying that the whole news is a lie and explains why. \\
\hline $\begin{array}{l}00: 03: 44- \\
00: 03: 46\end{array}$ & Azim & Asks a question of whether Libyans believe the news or not. \\
\hline $\begin{array}{l}00: 03: 47- \\
00: 03: 58\end{array}$ & Hamad & $\begin{array}{l}\text { Says he and other people do not believe the news or anything coming } \\
\text { from Gaddafi. }\end{array}$ \\
\hline $\begin{array}{l}00: 03: 58- \\
00: 04: 02\end{array}$ & Azim & Asks about the spirit of the revolutionaries. \\
\hline $\begin{array}{l}00: 04: 03- \\
00: 04: 45\end{array}$ & Hamad & $\begin{array}{l}\text { Answers the question about Gaddafi fears and his plans to safely get his } \\
\text { family out of the country. }\end{array}$ \\
\hline $\begin{array}{l}00: 04: 45- \\
00: 04: 59\end{array}$ & Azim & $\begin{array}{l}\text { Talks about the possibility of Gaddafi killing his own son because the } \\
\text { latter opposes his father's method of handling the uprising. }\end{array}$ \\
\hline $\begin{array}{l}00: 05: 00- \\
00: 05: 12\end{array}$ & Hamad & $\begin{array}{l}\text { Talks about the existence of all possibility: the possibilities that } \\
\text { Gaddafi's son is killed, fled the country or still alive. }\end{array}$ \\
\hline $\begin{array}{l}00: 05: 12- \\
00: 05: 15\end{array}$ & Azim & Asks about the situation with the Nafusa Mountain revolutionaries. \\
\hline $\begin{array}{l}00: 05: 15- \\
00: 06: 02\end{array}$ & Hamad & $\begin{array}{l}\text { Talks about how the mountain region came together and united against } \\
\text { Gaddafi. }\end{array}$ \\
\hline $\begin{array}{l}00: 06: 03- \\
00: 06: 06\end{array}$ & Azim & $\begin{array}{l}\text { Asks Hamad to stay with him in the studio to talk about other news } \\
\text { stories. }\end{array}$ \\
\hline $\begin{array}{l}00: 06: 07- \\
00: 06: 21\end{array}$ & Azim & $\begin{array}{l}\text { Read the next news story about the } 29 \text { people who were killed in Misrata } \\
\text { by the Gaddafi forces, how Gaddafi was targeting the city's seaport, and } \\
\text { how despite all of that, people come out and clean their city. }\end{array}$ \\
\hline
\end{tabular}




\begin{tabular}{|c|c|c|}
\hline $\begin{array}{l}00: 06: 23- \\
00: 07: 40\end{array}$ & Shukri & $\begin{array}{l}\text { Read aloud a report about the fight between the people of Misrata, on } \\
\text { the one side, and the Gaddafi forces and his mercenaries, on the other. } \\
\text { The report talks also about how people start cleaning their city after } \\
\text { each fight and how bombs are falling on children and women. Finally, } \\
\text { people in Misrata are determined to defeat the Gaddafi forces and } \\
\text { follow them until they reach Tripoli. }\end{array}$ \\
\hline $\begin{array}{l}00: 07: 41- \\
00: 07: 55\end{array}$ & Azim & $\begin{array}{l}\text { Asks Hamad to talk about the } 29 \text { people who died near the seaport of } \\
\text { Misrata. }\end{array}$ \\
\hline $\begin{array}{l}00: 07: 55- \\
00: 08: 41\end{array}$ & Hamad & $\begin{array}{l}\text { Starts with saluting the people of Misrata as they did with the people in } \\
\text { the mountain region. He emphasizes that the resistance in Misrata is } \\
\text { what gives Libyans a motive to resist and continue fighting. }\end{array}$ \\
\hline $\begin{array}{l}00: 08: 42- \\
00: 08: 46\end{array}$ & Azim & Asks why Misrata in particular. \\
\hline $\begin{array}{l}00: 08: 46- \\
00: 09: 15\end{array}$ & Hamad & $\begin{array}{l}\text { Explains why Misrata is very important for Gaddafi as a city and as a } \\
\text { seaport. }\end{array}$ \\
\hline $\begin{array}{l}00: 09: 15- \\
00: 09: 27\end{array}$ & Azim & $\begin{array}{l}\text { Asks about the strategy in the seaport between Gaddafi and the } \\
\text { revolutionaries. }\end{array}$ \\
\hline $\begin{array}{l}00: 09: 27- \\
00: 09: 57\end{array}$ & Hamad & $\begin{array}{l}\text { Explains that the strategy Gaddafi is following in Misrata is the same as } \\
\text { he had in the mountain area. }\end{array}$ \\
\hline $\begin{array}{l}00: 09: 57- \\
00: 10: 14\end{array}$ & Azim & $\begin{array}{l}\text { Says that the audience is wondering why Gaddafi is killing even those } \\
\text { families who fled the city despite the fact that they will do no harm to } \\
\text { him, but he kept following them to the seaport of Misrata or in the } \\
\text { mountain town of Diheiba. }\end{array}$ \\
\hline $\begin{array}{l}00: 10: 15- \\
00: 10: 26\end{array}$ & Hamad & $\begin{array}{l}\text { Says that Gaddafi is not easy, and he does not let anybody oppose him; } \\
\text { that is why he killed his opponents in some European capitals and } \\
\text { everywhere he can track them down. }\end{array}$ \\
\hline $\begin{array}{l}00: 10: 26- \\
00: 10: 29\end{array}$ & Azim & Wonders why Gaddafi kills women and children. \\
\hline $\begin{array}{l}00: 10: 29- \\
00: 10: 47\end{array}$ & Hamad & $\begin{array}{l}\text { Says that Gaddafi does that because he does not have Arab morality and } \\
\text { was not a good man. }\end{array}$ \\
\hline $\begin{array}{l}00: 10: 48- \\
00: 10: 54\end{array}$ & Azim & $\begin{array}{l}\text { Asks about support for the revolutionaries in Misrata and where it } \\
\text { comes from. }\end{array}$ \\
\hline $\begin{array}{l}00: 10: 55- \\
00: 11: 28\end{array}$ & Hamad & $\begin{array}{l}\text { Says that support comes from everywhere in Libya and all Libyans } \\
\text { support them. }\end{array}$ \\
\hline $\begin{array}{l}00: 11: 29 \\
00: 11: 35\end{array}$ & Azim & $\begin{array}{l}\text { Asks about Werfalla, whether they have made a move against Gaddafi } \\
\text { or not yet. }\end{array}$ \\
\hline $\begin{array}{l}00: 11: 35- \\
00: 11: 57\end{array}$ & Hamad & $\begin{array}{l}\text { Says that Gaddafi has very strong garrison in Werfalla, Tripoli, and } \\
\text { Sabratha, but people try their best by demonstrations and other means } \\
\text { and one day soon they will rebel like the other cities. }\end{array}$ \\
\hline $\begin{array}{l}00: 11: 57- \\
00: 12: 22\end{array}$ & Azim & $\begin{array}{l}\text { Reads a new news story about the movement of the media in the } \\
\text { Mountain region where new newspapers and magazines were recently } \\
\text { established. }\end{array}$ \\
\hline
\end{tabular}




\begin{tabular}{|c|c|c|}
\hline $\begin{array}{l}00: 12: 22- \\
00: 14: 10\end{array}$ & Shukri & $\begin{array}{l}\text { Reads a loud a report about the new newspaper and magazines that are } \\
\text { newly established in the Nafusa Mountain region towns and some } \\
\text { eastern cities like Tubruq and Benghazi. }\end{array}$ \\
\hline $\begin{array}{l}00: 14: 10- \\
00: 18: 50\end{array}$ & Azim & $\begin{array}{l}\text { Introduces and interviews Mazigh over the phone from Yefren. He is } \\
\text { the editor of one of the newspapers in Yefren. }\end{array}$ \\
\hline $\begin{array}{l}00: 14: 10- \\
00: 18: 50\end{array}$ & Mazigh & $\begin{array}{l}\text { He is interviewed over the phone by Azim to talk about newspapers and } \\
\text { magazines in the Nafusa Mountain region towns, and the difficulties } \\
\text { that are facing the distribution of these newspapers in Tripoli and other } \\
\text { parts of Libya. }\end{array}$ \\
\hline $\begin{array}{l}00: 18: 50- \\
00: 18: 59\end{array}$ & Azim & $\begin{array}{l}\text { Asks Hamad to comment of the new newspapers and magazines in the } \\
\text { Nafusa Mountain towns like Yefren, Nalut, and Jado. }\end{array}$ \\
\hline $\begin{array}{l}00: 19: 00- \\
00: 20: 23\end{array}$ & Hamad & $\begin{array}{l}\text { Says that he left the country a long time ago and he is not aware of the } \\
\text { development that recently took place in the Mountain region, but he } \\
\text { expresses his admiration to the new generation of young people who are } \\
\text { bringing these changes to light and make good use of the technology } \\
\text { available to them. }\end{array}$ \\
\hline $\begin{array}{l}00: 20: 23- \\
00: 20: 34\end{array}$ & Azim & $\begin{array}{l}\text { Asks whether or not the distribution of these newspapers will continue } \\
\text { under these circumstances of war. }\end{array}$ \\
\hline $\begin{array}{l}00: 20: 34- \\
00: 20: 57\end{array}$ & Hamad & $\begin{array}{l}\text { Says that with patience everything can be achieved and people need to } \\
\text { be patient and volunteer their time and effort. }\end{array}$ \\
\hline $\begin{array}{l}00: 20: 58- \\
00: 21: 36\end{array}$ & Azim & $\begin{array}{l}\text { Asks about the difference between Gaddafi's era and this new era in } \\
\text { terms of freedom of speech and restrictions on newspapers and other } \\
\text { media forms. }\end{array}$ \\
\hline $\begin{array}{l}00: 21: 36- \\
00: 23: 04\end{array}$ & Hamad & $\begin{array}{l}\text { Says that there are two things-freedom and determination and explains } \\
\text { how these two concepts contribute to the development of free speech } \\
\text { and free media. }\end{array}$ \\
\hline $\begin{array}{l}00: 23: 04- \\
00: 23: 21\end{array}$ & Azim & $\begin{array}{l}\text { Thanks Hamad and read a news headline about the people who fled } \\
\text { their towns, entered the Tunisian border, and live under harsh } \\
\text { conditions. }\end{array}$ \\
\hline $\begin{array}{l}00: 23: 22- \\
00: 23: 43\end{array}$ & Video & $\begin{array}{l}\text { A video for some fighter with machine gun standing in front of the } \\
\text { camera holding their fingers showing victory symbol, and unidentified } \\
\text { male voice asking them to take a group picture, and voices in the } \\
\text { background shouting Allahu Akbar "Allah is the greatest." Also in the } \\
\text { background, sounds of shots and another unidentified male voice saying } \\
\text { that "This is the Wazin border gate that the men just took over it." }\end{array}$ \\
\hline $\begin{array}{l}00: 23: 44- \\
00: 24: 11\end{array}$ & Girl & $\begin{array}{l}\text { A young girl standing in front of the camera talking about how Gaddafi } \\
\text { drove them out of their towns and why is the world is watching them } \\
\text { and doing nothing. She also urges the world to move fast against } \\
\text { Gaddafi. }\end{array}$ \\
\hline $\begin{array}{l}00: 24: 11- \\
00: 24: 29\end{array}$ & Azim & $\begin{array}{l}\text { Asks Hamad to comment on what the girl in the video was talking about } \\
\text { and to comment on the situation of the people who fled to the Tunisian } \\
\text { border and their suffering. }\end{array}$ \\
\hline
\end{tabular}




\begin{tabular}{|l|l|l|}
\hline $\begin{array}{l}\text { 00:24:29- } \\
00: 25: 21\end{array}$ & Hamad & $\begin{array}{l}\text { Says that this is a case of war, and where there is war, there is suffering. } \\
\text { Then it is natural that people who fled to Tunisia will be suffering from } \\
\text { lack of food and medication. He then urges them to be patient. }\end{array}$ \\
\hline $\begin{array}{l}\text { 00:25:21- } \\
00: 25: 26\end{array}$ & Azim & $\begin{array}{l}\text { Thanks Hamad and ends the broadcast by saluting the audience "peace } \\
\text { be with you." }\end{array}$ \\
\hline $\begin{array}{l}\text { 00:25:27- } \\
00: 25: 51\end{array}$ & Video & $\begin{array}{l}\text { The end of the broadcast music with the word "news" in Tamazight on } \\
\text { the screen. }\end{array}$ \\
\hline
\end{tabular}

